Check for updates

Cite this: RSC Adv., 2018, 8, 27131

Received 3rd July 2018

Accepted 24th July 2018

DOI: $10.1039 / \mathrm{c} 8 \mathrm{ra05690k}$

rsc.li/rsc-advances

\section{An efficient and ecofriendly synthesis of highly functionalized pyridones via a one-pot three- component reaction $\dagger$}

\author{
Hajar Hosseini (iD) and Mohammad Bayat (iD *
}

A simple and convenient protocol has been developed for the synthesis of $\mathrm{N}$-amino-3-cyano-2-pyridone derivatives by a one-pot reaction of cyanoacetohydrazide, activated nitrile substrates (malononitrile, ethyl cyanoacetate, cyanoacetamide) and aromatic aldehydes in the presence of piperidine in water or a mixture of water and ethanol. The sequence of cascade reactions includes Knoevenagel condensation, Michael addition, intramolecular cyclization, imine-enamine tautomerization and oxidative aromatization. The main advantages of this procedure are availability of starting compounds, simple procedure, mild conditions, easy purification of products and the use of water or water/ethanol as green solvents.

\section{Introduction}

The chemistry and applications of pyridine structures have recently attracted a lot of attention due to their uses as synthetic intermediates and their biological importance as agrochemicals, ${ }^{1-3}$ pharmaceuticals, ${ }^{4-8}$ dye intermediates, ${ }^{\mathbf{9}, 10}$ insecticides, adhesives, ${ }^{\mathbf{1 1}}$ antifungals, antibacterials, ${ }^{\mathbf{1 2 - 1 4}}$ antidepressant agents, ${ }^{15,16}$ and antitumor agents. ${ }^{17}$ In fact the pyridine ring has been found in more than 7000 drugs which are already in existence. $^{\mathbf{1 8}}$

Furthermore, 2-pyridones are a unique category of pharmacophores which exhibit several biological activities such as antitumoral, ${ }^{19}$ antimalarial, ${ }^{20}$ analgesic, ${ }^{21}$ and anti-HIV. ${ }^{22}$

Also cyanopyridines are important intermediates for the synthesis of nicotinamide, nicotinic acid and isonicotinic acid. 3-Cyano-2-pyridones are one of the biodynamic cyanopyridine derivatives (Scheme 1). ${ }^{23}$ The significance of 3-cyano-2-pyridone frameworks in the past few decades is undeniable. For example they are the structural basis of the alkaloid ricinine, the first known alkaloid containing a cyano group. Milrinone is a 3cyano-2-pyridone derivative that has been used for the treatment of congestive heart failure. ${ }^{\mathbf{2 4 , 2 5}}$ Another derivative 3-cyano2-pyridone has shown anticancer activity which might be due to the interference of the molecule with PDE-3, ${ }^{26}$ PIM-1 kinase, ${ }^{27}$ and survivin protein. ${ }^{28}$

Due to the great importance of this skeleton, the development of efficient and environmentally benign methodologies for the synthesis of diverse functionalized 2-pyridones is still

Department of Chemistry, Faculty of Science, Imam Khomeini International University, Qazvin, Iran. E-mail: bayat_mo@yahoo.com; m.bayat@sci.ikiu.ac.ir; Tel: +98(28) 33780040

$\dagger$ Electronic supplementary information (ESI) available. See DOI: 10.1039/c8ra05690k highly desired. There are some strategies for the synthesis of 3cyano-2-pyridone derivatives which already have been reported, most of them proceed through the regioselective cyclocondensation of an acetonitrile derivative (cyanoacetate ester, cyanoacetamide or malononitrile) with a suitable carbonyl substrate in a $[3+3]$ mode. In fact, Michael addition of acetonitrile derivatives to an appropriate carbonyl substrate (1,3dicarbonyl or $\alpha, \beta$-unsaturated compound) and subsequent hydrolytic cyclization followed by oxidative aromatization leads to the corresponding 3-cyano-2-pyridones. Here, we outline some of the most efficient methods (Scheme 2).

Reaction of malononitrile, ethyl cyanoacetate and aromatic aldehydes in a two-step reaction led to corresponding 3-cyano-2pyridones (A). ${ }^{29}$ In another work the reaction of various enones with cyanoacetamide, led to 3-cyano-2-pyridones by operating

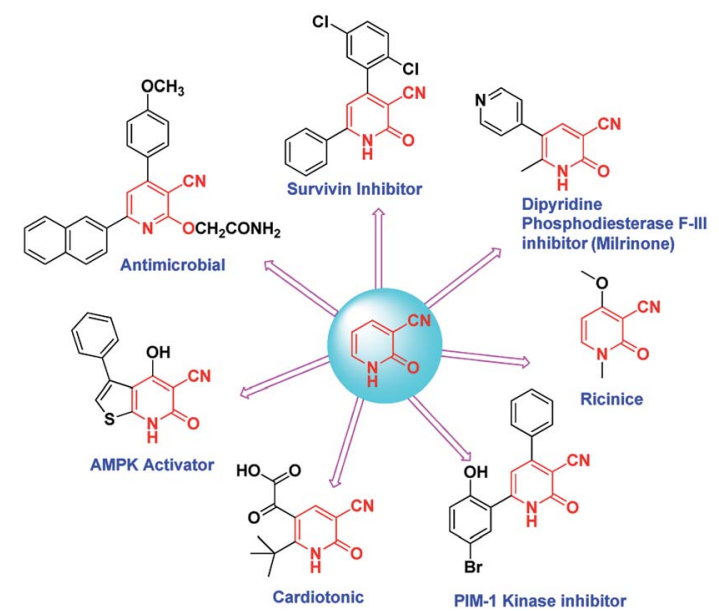

Scheme 1 Biodynamic activities of different derivatives of 3-cyano-2pyridone. 


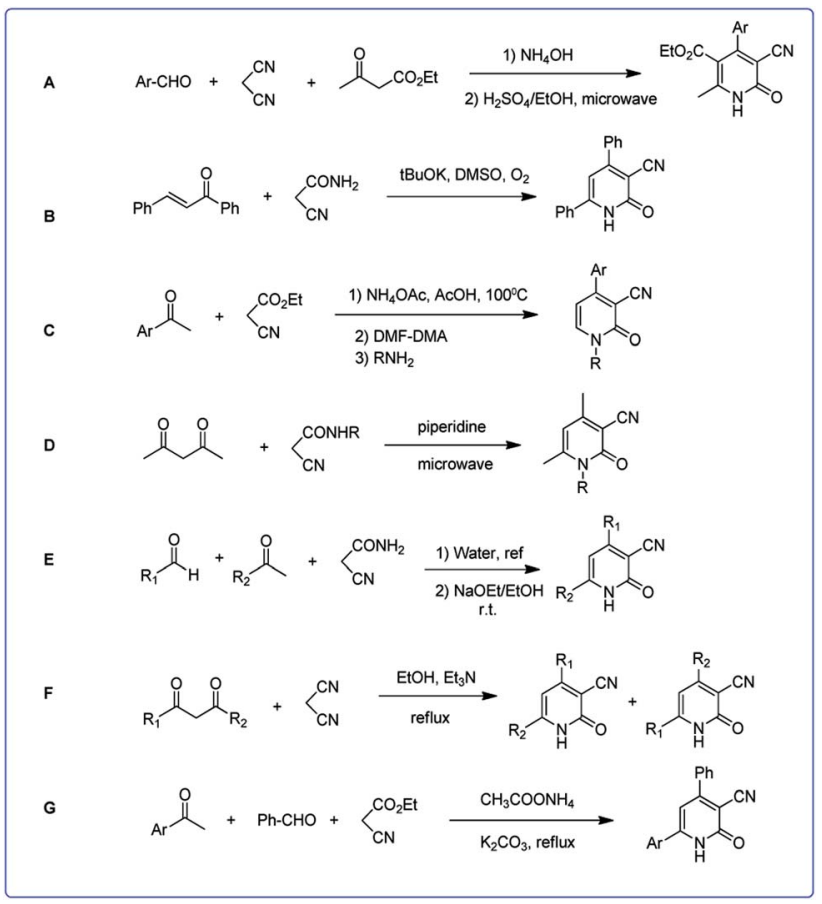

Scheme 2 Summary of previous studies of 3-cyano-2-pyridones synthesis.

in DMSO and in the presence of excess $t$-BuOK under an oxygen atmosphere (B).$^{30}$ The Knoevenagel product of aromatic ketones and ethyl acetoacetate reacted with $N, N$-dimethylformamidedimethylacetal (DMF-DMA) to produce enaminonitriles. By adding various types of primary nucleophilic amines to enaminonitrile, 3-cyano-2-pyridone derivatives were formed (C). ${ }^{31}$

Condensation of acetylacetone and corresponding $\mathrm{N}$ substituted cyanoacetamide using microwave irradiation led to pyridones (D). ${ }^{32}$ In a two-step reaction, firstly acrylamides were obtained via the reaction of aromatic aldehydes and cyanoacetamide in water, then acrylamides were reacted with enolates to produce corresponding 2-pyridones (E) ${ }^{33}$

Also 3-cyano-2-pyridinone derivatives were prepared in the reaction of 1,3-dicarbonyl compounds with malononitrile followed by cycloaddition and isomerization $(\mathbf{F}) .^{34}$ In another study a one-pot reaction of acetophenone derivatives, malononitrile or ethyl cyanoacetate, an aldehyde, and ammonium acetate in the presence of $\mathrm{K}_{2} \mathrm{CO}_{3}$ led to the corresponding structures $(\mathbf{G}){ }^{35}$

Many of the established procedures carried out under harsh reaction conditions. On the other hand, one of the goals in modern synthetic organic chemistry includes the use of safer, easier and more effective methods.

\section{Results and discussion}

Here we report a one-pot three-component reaction between cyanoacetohydrazide, acetonitrile derivatives (malononitrile, ethyl cyanoacetate, cyanoacetamide) and aromatic aldehydes. This strategy led to the $\mathrm{N}$-amino-3-cyano-2-pyridones in good yields via a multicomponent reaction. Multicomponent reactions (MCRs) are extremely convergent one-pot processes, in which three or more reagents are combined sequentially to create complex products, with almost all the atoms coming from the starting reagents. ${ }^{36-39}$

The reaction of cyanoacetohydrazide, malononitrile or ethyl cyanoacetate and aldehydes has been reported in 1984 and 1997 with different procedure and there are no complete spectral data about the structures of products. ${ }^{40,41}$ Furthermore, synthesis of pyridones using of both cyanoacetamide and cyanoacetohydrazide has not been reported so far.

We succeeded in synthesizing three categories of highly functionalized 2-pyridone structures containing 1,6-diamino-4aryl-2-oxo-1,2-dihydropyridine-3,5-dicarbonitrile, ethyl 1,6diamino-4-aryl-3-cyano-2-oxo-1,2-dihydropyridine-5-carboxylate and 1,6-diamino-4-aryl-3-cyano-2-oxo-1,2-dihydropyridine-5carboxamide.

Continuing our research on multi-component reactions using cyanoacetohydrazide, we will describe in this paper a very efficient and environmentally benign strategy for the synthesis of $\mathrm{N}$-amino-3-cyano-2-pyridone derivatives by a one-pot three component reaction of cyanoacetohydrazide $\mathbf{1}$, acetonitrile derivatives $\mathbf{2}$ (malononitrile $\mathbf{2 a}$, ethyl cyanoacetate $\mathbf{2 b}$, cyanoacetamide 2c) and aromatic aldehydes $\mathbf{3}$ (Scheme 3 ).

For the better study of reactions and procedures and more detailed examination of structures, we divide the reactions into three class based on malononitrile $\mathbf{2} \mathbf{a}$, ethyl cyanoacetate $\mathbf{2 b}$ and cyanoacetamide $\mathbf{2 c}$.

As the first group of reactions, we used cyanoacetohydrazide 1, malononitrile 2a and aromatic aldehydes 3a-1 in different conditions. The best results were obtained in water in the presence of piperidine as catalyst at room temperature. We could synthesize 12 pyridone derivatives with various aldehydes. In all of these reactions, 1,6-diamino-4-aryl-3,5-dicyano2-pyridone 4a-1 were obtained with high efficiency and relatively short time (Table 1 ). The structures of compounds $\mathbf{4 a - 1}$ were derived from their IR, ${ }^{1} \mathrm{H}$ NMR, ${ }^{13} \mathrm{C}$ NMR spectroscopic and mass spectrometric data (see the ESI $\dagger$ ).

By comparing the reaction rates in the table above, it is found that for aldehydes with an electron withdrawing group on the ring (nitro and halogens), the reaction rate is the highest and with electron donating groups (methoxy), the speed is the lowest.

Here we investigate the ${ }^{1} \mathrm{H}$ and ${ }^{13} \mathrm{C}$ NMR spectra of product 4a. As shown in Fig. 1, the ${ }^{1} \mathrm{H}$ NMR spectrum of 4 a showed two signals at $\delta 5.65$ and $8.51 \mathrm{ppm}$ identified as $\mathrm{N}-\mathrm{NH}_{2}$ and $\mathrm{NH}_{2}$

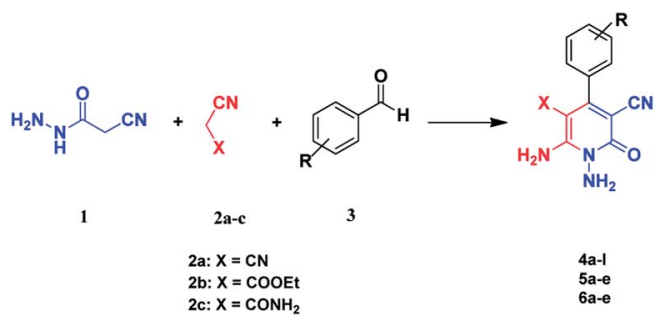

Scheme 3 Synthetic scheme for generation of products $4,5,6$. 
Table 1 Synthesis of 1,6-diamino-4-aryl-2-oxo-1,2-dihydropyridine-3,5-dicarbonitrile 4a-l ${ }^{a}$

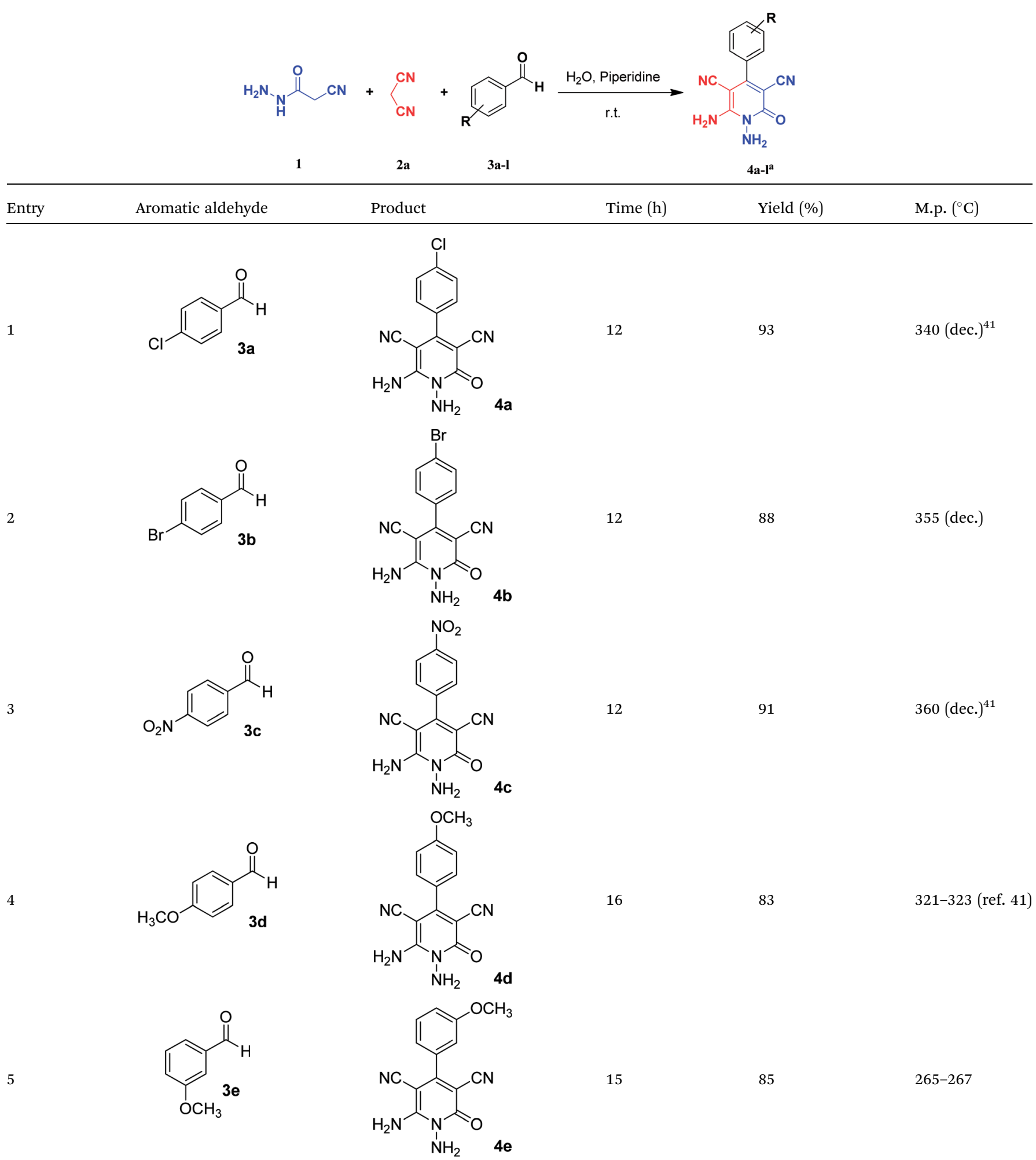




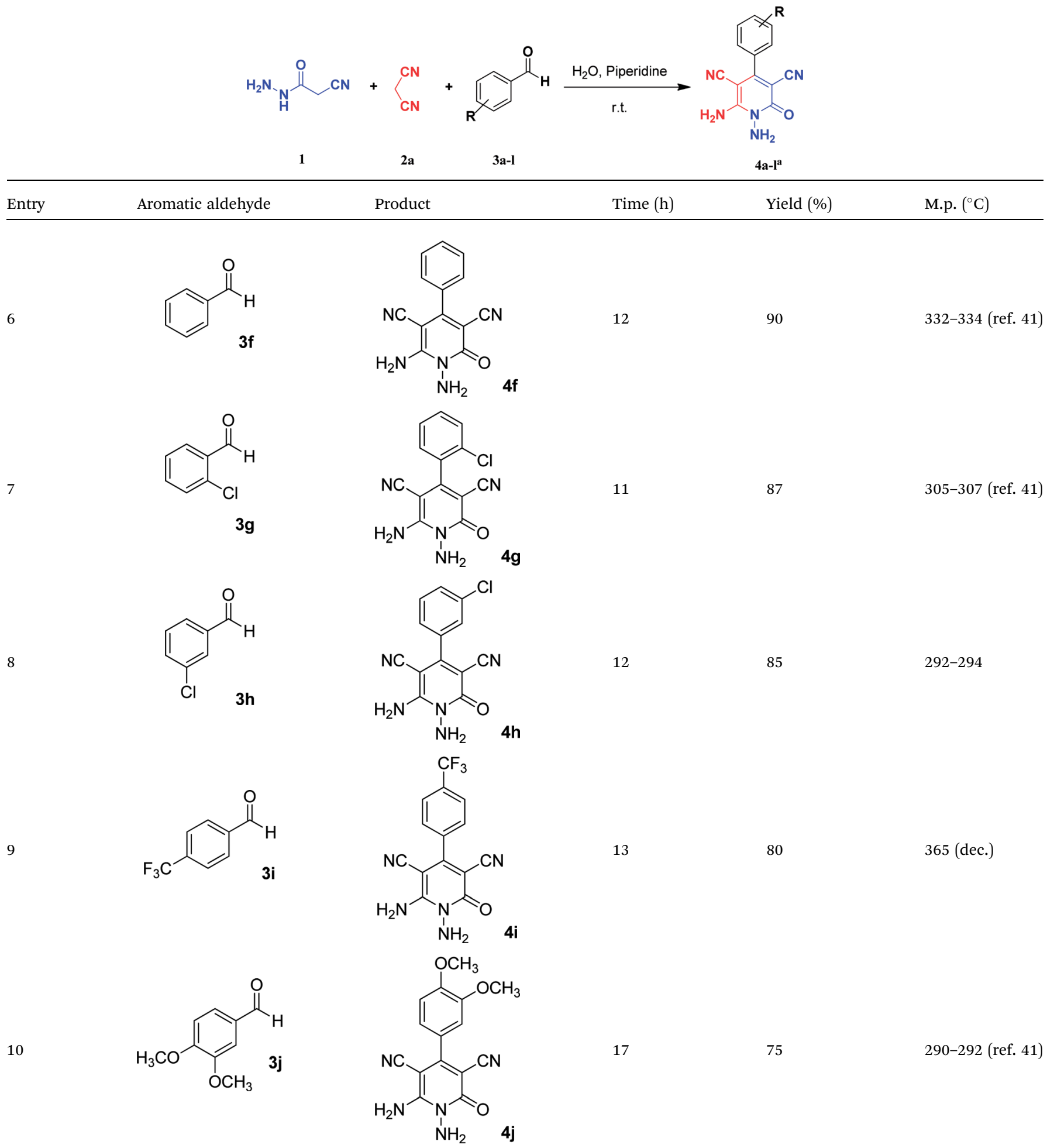


Table 1 (Contd.)

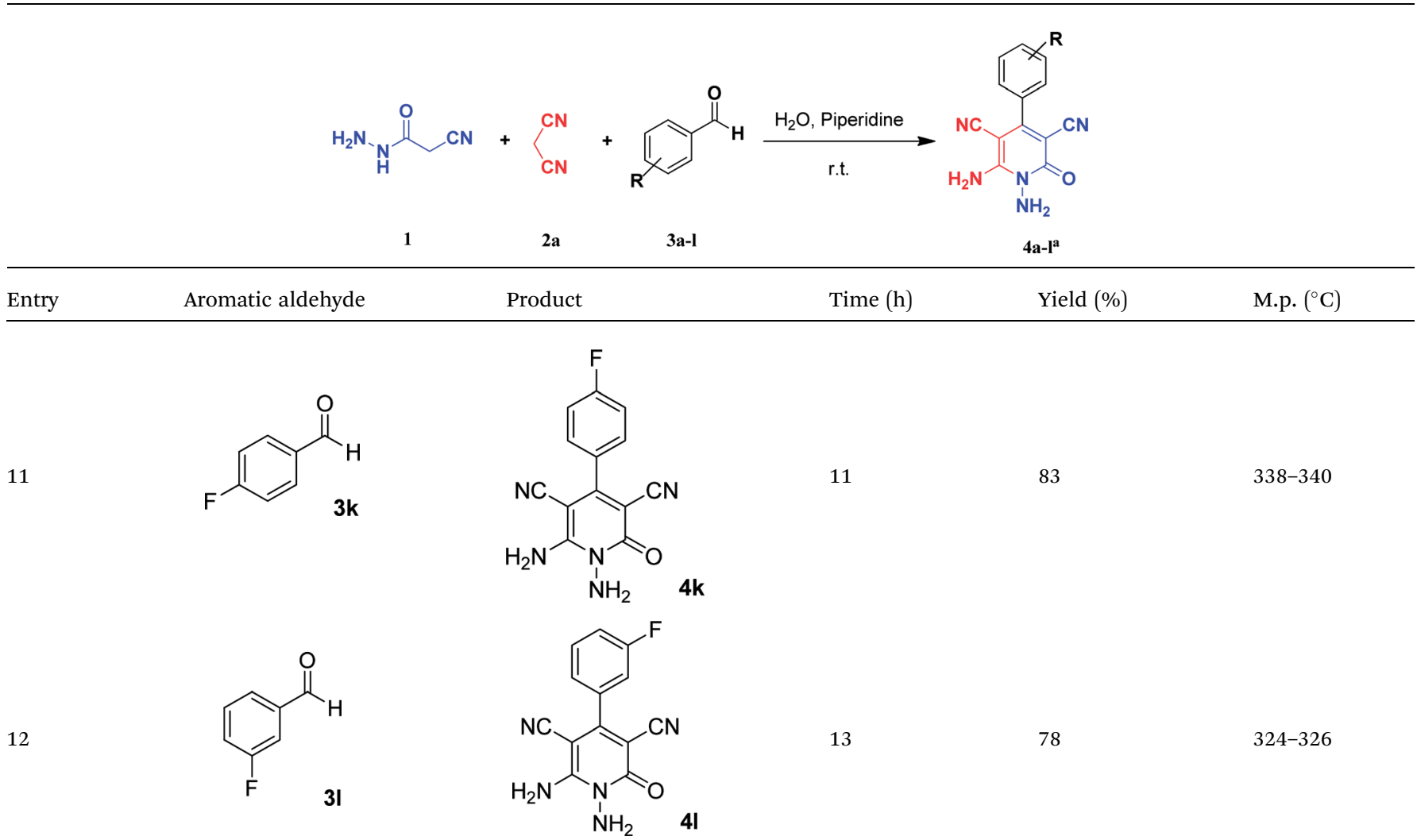

\footnotetext{
${ }^{a}$ All reactions were carried out with cyanoacetohydrazide 1 ( $\left.1 \mathrm{mmol}\right)$, malononitrile $2 \mathrm{a}(1 \mathrm{mmol})$, aromatic aldehydes 3 ( 1 mmol) and piperidine $(0.02 \mathrm{mmol})$ in water $(10 \mathrm{ml})$.
}
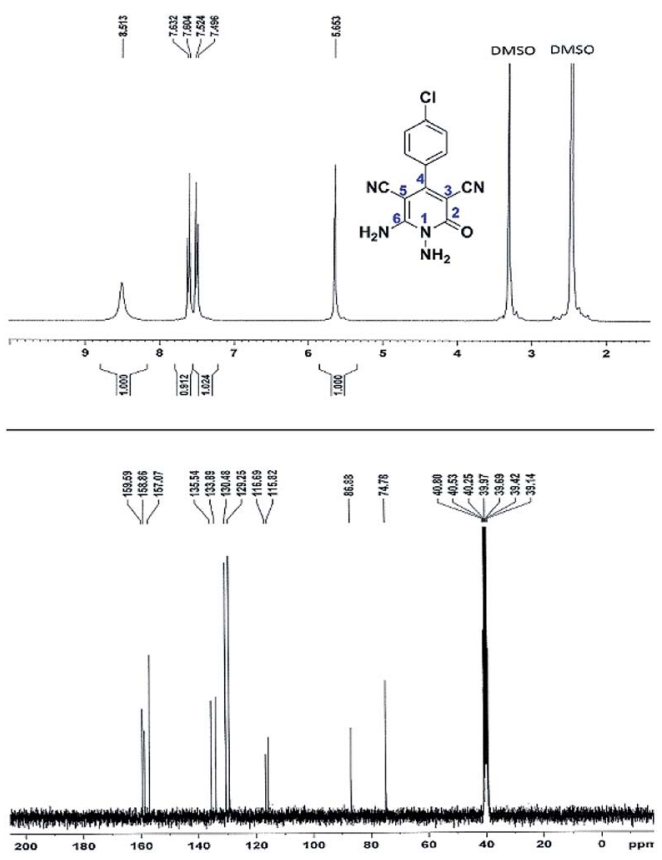

Fig. 1 The ${ }^{1} \mathrm{H}$ and ${ }^{13} \mathrm{C}$ NMR spectrums of $4 \mathrm{a}$. groups respectively. These peaks were exchangeable with $\mathrm{D}_{2} \mathrm{O}$. The four protons of aromatic ring appeared at $\delta 7.50$ and $7.62 \mathrm{ppm}$ as two doublets. The ${ }^{1} \mathrm{H}$-decoupled ${ }^{13} \mathrm{C}$ NMR spectrum of $\mathbf{4 a}$ indicated 11 distinct resonances in accordance to desired structure. Two signals of C-5 and C-3 of pyridone ring were observed at $\delta 74.7$ and $86.8 \mathrm{ppm}$ respectively. The signals at $\delta 115.8$ and $116.6 \mathrm{ppm}$ were related to two nitrile groups. The signals at $\delta 129.2,130.4,133.8$ and $135.5 \mathrm{ppm}$ were assigned to carbons of aryl ring. The carbons of C-4 and C- 6 appeared at $\delta 157.0$ and $158.8 \mathrm{ppm}$. The carbonyl group (C-2) was observed at $\delta 159.5$ ppm (Fig. 1).

The mass spectrum of $\mathbf{4 a}$ displayed the molecular-ion peak at $m / z 285(100 \%)$ in agreement with the proposed structure. The IR spectrum of this compound showed absorption bands at 3390,3283 due to the $\mathrm{NH}_{2}$ groups, stretching vibration of nitrile groups at 2216, strong absorption of carbonyl group at 1623 , $\mathrm{N}-\mathrm{H}$ bending band at 1525 , stretching vibration of $\mathrm{C}=\mathrm{C}$ of aromatic ring at 1465 and $\mathrm{C}-\mathrm{N}$ band at $1227 \mathrm{~cm}^{-1}$.

According to the above findings, we used ethyl cyanoacetate instead of malononitrile. As a result, ethyl 1,6-diamino-4-aryl-3cyano-2-pyridone-5-carboxylate derivatives 5a-e were synthesized via the reaction of cyanoacetohydrazide $\mathbf{1}$, ethyl cyanoacetate $\mathbf{2 b}$ and the five aldehydes $\mathbf{3}$ (Table 2). The best results in 
Table 2 Synthesis of ethyl 1,6-diamino-4-aryl-3-cyano-2-oxo-1,2-dihydropyridine-5-carboxylate 5a-e ${ }^{a}$

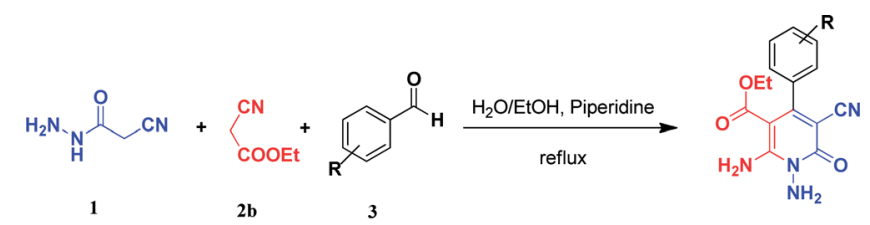

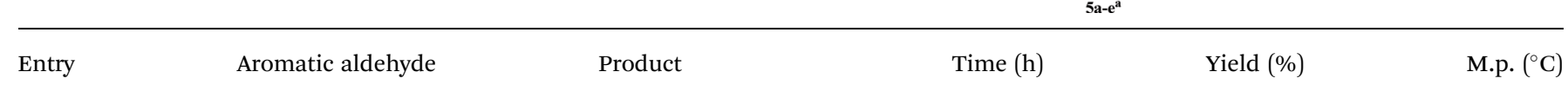

1<smiles>O=Cc1ccc(Cl)cc1</smiles>

2<smiles>O=Cc1ccc(Br)cc1</smiles>

3<smiles>O=Cc1ccccc1Cl</smiles>

4

5<smiles>O=Cc1cccc(F)c1</smiles><smiles>O=Cc1ccc(F)cc1</smiles><smiles>CCOC(=O)c1c(C#N)c(C#N)c(=O)n(N)c1N</smiles><smiles>N#Cc1cc(C(=O)OCCl)c(N)n(N)c1=O</smiles><smiles>CCOC(=O)c1c(-c2ccc(F)cc2)c(C#N)c(=O)n(N)c1N</smiles>

\footnotetext{
${ }^{a}$ All reactions were carried out with cyanoacetohydrazide 1 ( $\left.1 \mathrm{mmol}\right)$, ethyl cyanoacetate $2 \mathbf{b}(1 \mathrm{mmol})$, aromatic aldehydes 3 ( $\left.1 \mathrm{mmol}\right)$ and piperidine $(0.02 \mathrm{mmol})$ in water/EtOH $(5: 5 \mathrm{~mL})$.
}

this type of reactions were obtained in the mixture of water and ethanol $(1: 1, \mathrm{v} / \mathrm{v})$ in the presence of piperidine at reflux conditions (these reactions in water led to the hydrazone products without participation of ethyl cyanoacetate).
The reaction with other aromatic aldehydes was carried out similar to the high work, but did not result in the expected products and the reaction mixture showed several spots in TLC (the desired product was not isolable). 
It is interesting to note that when methyl cyanoacetate was used instead of ethyl cyanoacetate in the above reaction, the same ethyl carboxylate products 5a-e were obtained.

The spectral analysis of IR, ${ }^{1} \mathrm{H}$ NMR, ${ }^{13} \mathrm{C}$ NMR and mass spectrums of 5a-e confirmed the formation of expected structures (see the ESI $\dagger$ ). For example the ${ }^{1} \mathrm{H}$ NMR spectrum of $5 \mathbf{a}$ showed a triplet at $\delta 0.57$ and a quartet at $\delta 3.73 \mathrm{ppm}$ related to the $\mathrm{CH}_{3}$ and $\mathrm{CH}_{2}$ groups. Protons of $\mathrm{N}-\mathrm{NH}_{2}$ group was observed at $\delta 5.56 \mathrm{ppm}$. The signals of aromatic ring specified at $\delta 7.25$ and $7.48 \mathrm{ppm}$ as two doublets. Two broad signals related to the $\mathrm{NH}_{2}$ group (position 6) appeared at $\delta 8.42$ and $8.72 \mathrm{ppm}$ separately as a result of intramolecular hydrogen bonding. The ${ }^{1} \mathrm{H}$ decoupled ${ }^{13} \mathrm{C}$ NMR spectrum of 5 a displayed 13 distinct signals in accordance with expected structure. The carbons of methyl and methylene groups appeared at $\delta 13.2$ and $60.5 \mathrm{ppm}$ respectively. The signals of $\mathrm{C}-3$ and $\mathrm{C}-5$ of pyridone ring were observed at $\delta 88.1$ and $91.4 \mathrm{ppm}$. The nitrile group was assigned at $\delta 117.0$ The signals at $\delta 129.2,130.4,133.8$ and $135.5 \mathrm{ppm}$ were related to carbons of aryl ring. The carbons of C-4 and C-6 appeared at $\delta 156.6$ and $158.6 \mathrm{ppm}$. Two carbonyl groups (C-2 and $\mathrm{CO}_{2} \mathrm{Et}$ ) were observed at $\delta 159.2$ and $166.16 \mathrm{ppm}$ respectively (Fig. 2).

The mass spectrum of $\mathbf{5 a}$ afforded a molecular-ion peak at $\mathrm{m} /$ $z 332(100 \%)$ in conformity with the proposed product. The IR spectrum of this compound indicated absorption bands due to $\mathrm{NH}_{2}$ groups broadly at 3387 and 3266, stretching vibrations of aliphatic C-H bands at 2984, 2923, one vibration of nitrile group at 2215, strong absorptions of carbonyl groups at 1686 and $1651, \mathrm{~N}-\mathrm{H}$ bending band at 1536, stretching vibration of $\mathrm{C}=\mathrm{C}$ of aromatic ring at 1473 and $\mathrm{C}-\mathrm{N}$ stretching band at $1207 \mathrm{~cm}^{-1}$.

In the third section, we used cyanoacetamide as activated nitrile compound. As a result, the reaction of
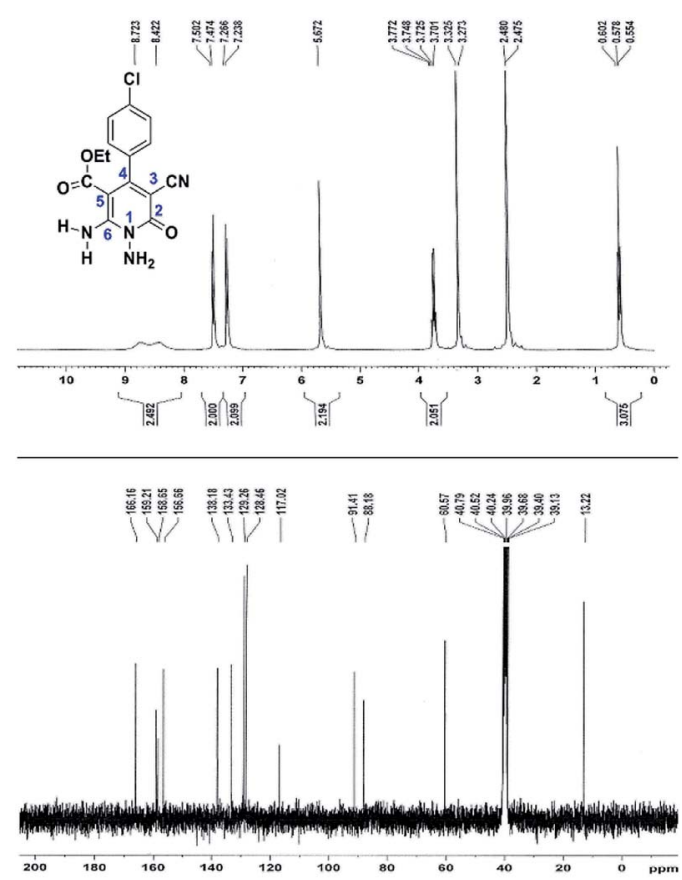

Fig. 2 The ${ }^{1} \mathrm{H}$ and ${ }^{13} \mathrm{C}$ NMR spectrums of $5 \mathrm{a}$. cyanoacetohydrazide $\mathbf{1}$, cyanoacetamide $2 \mathrm{c}$ and some aromatic aldehydes 3 led to 1,6-diamino-4-aryl-3-cyano-2-pyridone-5carboxamide derivatives 6a-e (Table 3). It was investigated that the best results were obtained in the mixture of water and ethanol $(1: 2, \mathrm{v} / \mathrm{v})$ in the presence of piperidine at reflux conditions (similar to the previous reactions, when water was used alone, the hydrazone compounds were formed as only products).

This reaction with other aromatic aldehydes was carried out similar to the first work, but did not led to the pure products and the reaction mixture contained several spots in TLC (the expected product was not separable).

The structures of products $\mathbf{6 a - e}$ were deduced from their IR, ${ }^{1} \mathrm{H}$ NMR, ${ }^{13} \mathrm{C}$ NMR spectroscopic and mass spectrometric data (see the ESI $\dagger$ ). Here we study the ${ }^{1} \mathrm{H}$ and ${ }^{13} \mathrm{C}$ NMR spectra of $6 \mathbf{a}$. As seen in Fig. 3, the ${ }^{1} \mathrm{H}$ NMR spectrum of $6 \mathbf{a}$ indicated a singlet at $\delta 5.67 \mathrm{ppm}$ identified as the $\mathrm{N}-\mathrm{NH}_{2}$ group. Two singlet broad signals at $\delta 6.85$ and $7.22 \mathrm{ppm}$ were assigned to the amino group (on C-6). Two doublets at $\delta 7.28$ and $7.65 \mathrm{ppm}$ were related to aryl ring. The amidic $\mathrm{NH}_{2}$ group appeared at $\delta 7.78 \mathrm{ppm}$. The ${ }^{1} \mathrm{H}$-decoupled ${ }^{13} \mathrm{C}$ NMR spectrum of 6 a showed 11 resonances which confirmed the assumed structure. The signals of C-3 and C-5 were observed at $\delta 83.7$ and $99.4 \mathrm{ppm}$ respectively. The nitrile group appeared at $\delta 118.1 \mathrm{ppm}$. The signals at $\delta$ 123.0, $130.8,131.6$ and 136.1 were related to aryl ring. The carbons of C-4 and C-6 were observed at $\delta 153.8$ and $154.0 \mathrm{ppm}$. Two carbonyl groups $\left(\mathrm{C}-2\right.$ and $\left.\mathrm{CONH}_{2}\right)$ were assigned at $\delta 159.6$ and 167.3 ppm respectively (Fig. 3).

The mass spectrum of $\mathbf{6 a}$ showed the molecular-ion peak at $\mathrm{m} / z 347(100 \%)$ that was in accordance with the desired structure. The IR spectrum of compound 6a showed absorption broad bands at 3394, 3290 related to the $\mathrm{NH}_{2}$ groups, stretching vibrations of nitrile group at 2205, strong absorption of carbonyl groups at 1662 and 1612, N-H bending band at 1571, stretching vibration of $\mathrm{C}=\mathrm{C}$ of aromatic ring at 1463 and $\mathrm{C}-\mathrm{N}$ stretching band at $1213 \mathrm{~cm}^{-1}$.

A plausible mechanism for the formation of 2-pyridones $\mathbf{4 , 5}$ and 6 is depicted in Scheme 4. Initial condensation of activated nitriles 2 with aromatic aldehydes 3 in the presence of piperidine, leads to the Knoevenagel products 7 . The methylene group of cyanoacetohydrazide loses proton with the catalyst so subsequent Michael addition of cyanoacetohydrazide $\mathbf{1}$ to adduct 7 affords intermediate 8 which undergoes intramolecular cyclisation via nucleophilic addition of -NH to nitrile group to give the corresponding 1-amino-6-imino-2piperidinone 9. Successive imine-enamine tautomerization followed by dehydrogenation affords desired products (Scheme 4).

It is necessary to mention this point that cyanoacetohydrazide could conceivably lead to condensation at the hydrazide group with aldehydes, but even when the hydrazone structures were synthesized and added to compounds 2, the same pyridone products were obtained. In fact, the most important part of these reactions was the prevention of hydrazone formation, which was controlled with the mentioned conditions. 
Table 3 Synthesis of 1,6-diamino-4-aryl-3-cyano-2-oxo-1,2-dihydropyridine-5-carboxamide 6a-e ${ }^{a}$

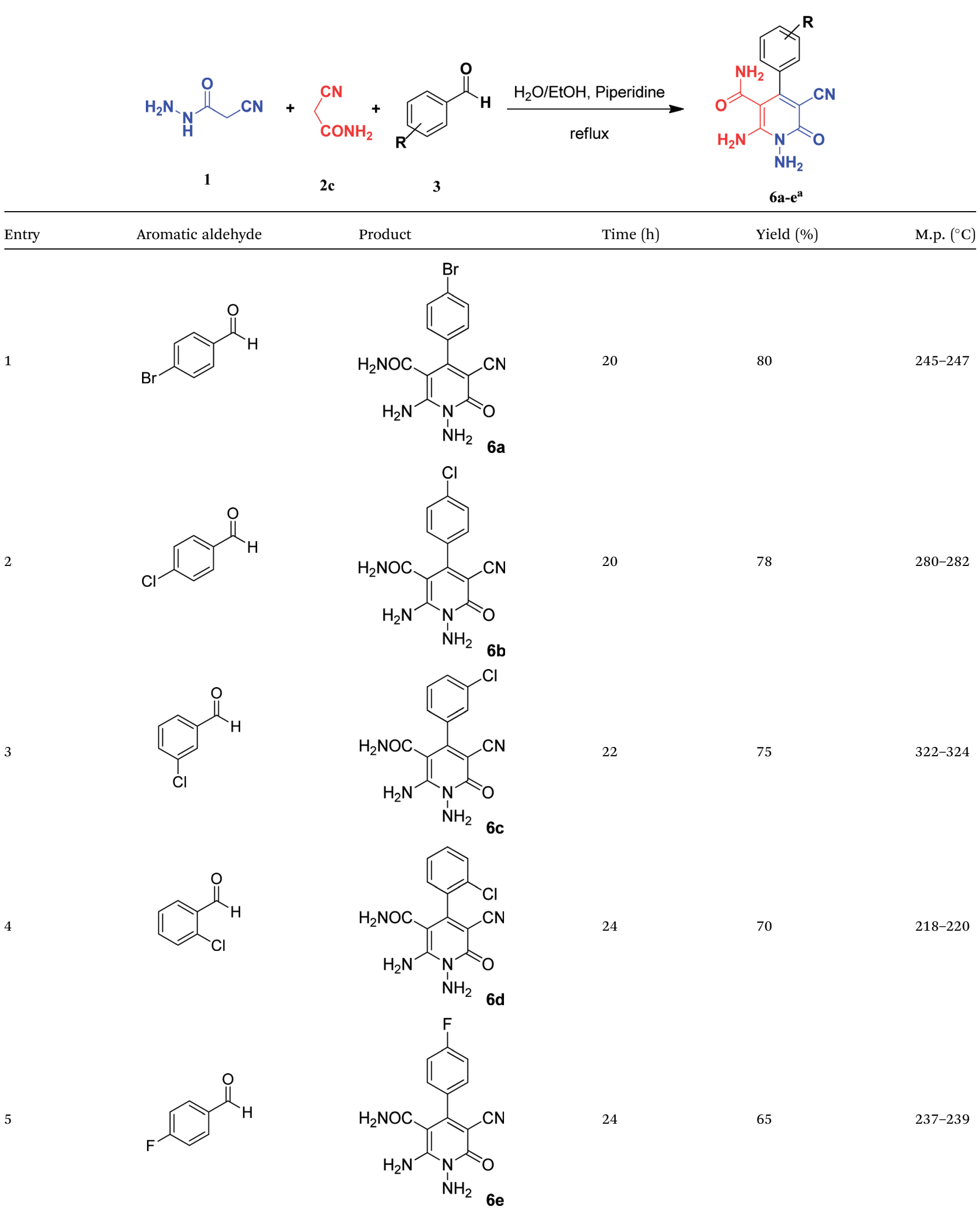
${ }^{a}$ All reactions were carried out with cyanoacetohydrazide $1(1 \mathrm{mmol})$, cyanoacetamide $2 \mathrm{c}(1 \mathrm{mmol})$, aromatic aldehydes 3 (1 mmol) and piperidine
$(0.02 \mathrm{mmol})$ in water/EtOH $(3: 6 \mathrm{~mL})$. 

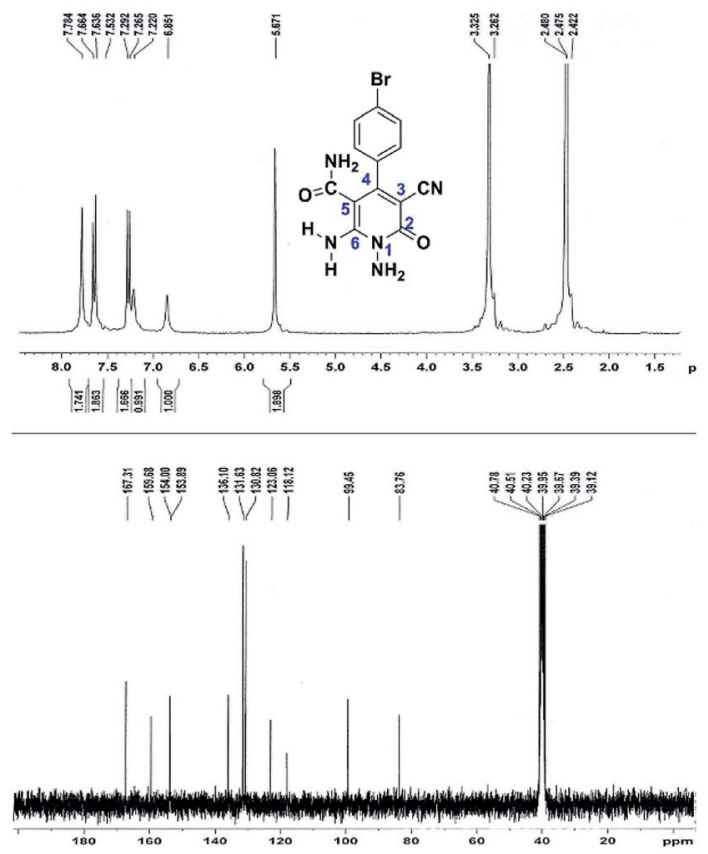

Fig. 3 The ${ }^{1} \mathrm{H}$ and ${ }^{13} \mathrm{C}$ NMR spectrums of 6 a.

\section{Experimental}

\section{Materials}

All commercially available reagents and other solvents were purchased and used without further purification. The NMR spectra were recorded with a Bruker DRX-300 Avance instrument (300 MHz for ${ }^{1} \mathrm{H}$ and $75.4 \mathrm{MHz}$ for ${ }^{13} \mathrm{C}$ ) with DMSO- $d_{6}$ as solvent. Chemical shifts are given in ppm $(\delta)$, and coupling constant $(J)$ are reported in hertz $(\mathrm{Hz})$. Melting points were measured with an electrotherma1 9100 apparatus. Mass spectra were recorded with an Agilent 5975C VL MSD with Triple-Axis Detector operating at an ionization potential of $70 \mathrm{eV}$. IR spectra were measured with, Bruker Tensor 27 spectrometer $(\bar{\nu}$ in $\mathrm{cm}^{-1}$ ). Elemental analyses for $\mathrm{C}, \mathrm{H}$ and $\mathrm{N}$ were performed using a PerkinElmer 2004 series [II] CHN elemental analyzer.

General procedure for the synthesis of 1,6-diamino-4-aryl-2oxo-1,2-dihydropyridine-3,5-dicarbonitrile (4a-1)

The stoichiometric mixture of cyanoacetohydrazide 1 ( $1 \mathrm{mmol}$, $0.99 \mathrm{~g}$ ), malononitrile $2 \mathrm{a}$ ( $1 \mathrm{mmol}, 0.66 \mathrm{~g})$, aromatic aldehyde $3 \mathrm{a}-\mathbf{l}(1 \mathrm{mmol})$ and piperidine $(20 \% \mathrm{~mol}, 0.019 \mathrm{ml})$ in $\mathrm{H}_{2} \mathrm{O}(10$ $\mathrm{ml}$ ) was stirred at room temperature. The progress of the reaction was monitored by TLC using ethyl acetate/ $n$-hexane $(1: 1)$. After completion of the reaction, the precipitated product was collected by filtration and washed with warm ethanol to give the pure products $\mathbf{4 a}-\mathbf{l}$.

1,6-Diamino-4-(4-chlorophenyl)-2-oxo-1,2-dihydropyridine3,5-dicarbonitrile (4a). White solid; yield: $0.265 \mathrm{~g}$ (93\%); mp: $340{ }^{\circ} \mathrm{C}$ (dec.); IR (KBr) $\left(\nu_{\max } / \mathrm{cm}^{-1}\right): 3390,3283,3197,2216,1623$, 1525, 1465, 1227, 841, 766; ${ }^{1} \mathrm{H}$ NMR (300 MHz, DMSO): $\delta 5.65$ (s, $\left.2 \mathrm{H}, \mathrm{N}-\mathrm{NH}_{2}\right), 7.51(\mathrm{~d}, J=8.4 \mathrm{~Hz}, 2 \mathrm{H}, \mathrm{ArH}), 7.62(\mathrm{~d}, J=8.4 \mathrm{~Hz}, 2 \mathrm{H}$, ArH), 8.51 (brs, 2H, $\mathrm{NH}_{2}$ ); ${ }^{13} \mathrm{C}\left\{{ }^{1} \mathrm{H}\right\}$ NMR (75.4 MHz, DMSO): $\delta 74.7(C-\mathrm{CN}), 86.8(C-\mathrm{CN}), 115.8(\mathrm{CN}), 116.6(\mathrm{CN}), 129.2,130.4$, 133.8, 135.5 (Ar), 157 (C-4), $158.8\left(\mathrm{C}-\mathrm{NH}_{2}\right), 159.5(\mathrm{C}=\mathrm{O})$; MS (EI, $70 \mathrm{eV}): m / z(\%)=287(35)[\mathrm{M}+2]^{+}, 286(18)[\mathrm{M}+1]^{+}, 285$ (100) $[\mathrm{M}]^{+}, 256$ (19), 241 (20), 205 (13), 193 (7), 161 (10), 138 (5), 111 (4), 88 (3), 75 (6), 58 (3), 43 (2); anal. calcd for $\mathrm{C}_{13} \mathrm{H}_{8} \mathrm{ClN}_{5} \mathrm{O}: \mathrm{C}$, $54.65 ; \mathrm{H}, 2.82 ; \mathrm{N}, 24.51$. Found: C, 54.65; H, 2.71; N, 24.39.

1,6-Diamino-4-(4-bromophenyl)-2-oxo-1,2-dihydropyridine3,5-dicarbonitrile (4b). White solid; yield: $0.289 \mathrm{~g}$ (88\%); mp: $355^{\circ} \mathrm{C}$ (dec.); IR (KBr) $\left(\nu_{\max } / \mathrm{cm}^{-1}\right): 3450,3396,3258,2212,1600$, 1522, 1466, 1297, 829, 613; ${ }^{1} \mathrm{H}$ NMR (300 MHz, DMSO): $\delta 5.64(\mathrm{~s}$, $2 \mathrm{H}, \mathrm{N}-\mathrm{NH}_{2}$ ), 7.43 (d, $\left.J=8.1 \mathrm{~Hz}, 2 \mathrm{H}, \mathrm{ArH}\right), 7.59(\mathrm{~d}, J=8.1 \mathrm{~Hz}, 2 \mathrm{H}$, ArH), 8.50 (brs, $2 \mathrm{H}, \mathrm{NH}_{2}$ ); ${ }^{13} \mathrm{C}\left\{{ }^{1} \mathrm{H}\right\} \mathrm{NMR}$ (75.4 MHz, DMSO): $\delta 74.7(C-\mathrm{CN}), 86.7(C-\mathrm{CN}), 115.8(\mathrm{CN}), 116.6(\mathrm{CN}), 124.3,130.6$, 132.1, 134.2 (Ar), 157 (C-4), $158.8\left(\mathrm{C}-\mathrm{NH}_{2}\right), 159.5(\mathrm{C}=\mathrm{O})$; MS (EI, $70 \mathrm{eV}): m / z(\%)=331(98)[\mathrm{M}+2]^{+}, 330(21)[\mathrm{M}+1]^{+}, 329(100)$ $[\mathrm{M}]^{+}, 300$ (12), 285 (17), 258 (6), 222 (14), 205 (26), 193 (14), 165 (12), 152 (13), 126 (14), 100 (9), 88 (7), 75 (10), 58 (6), 43 (3); anal. calcd for $\mathrm{C}_{13} \mathrm{H}_{8} \mathrm{BrN}_{5} \mathrm{O}: \mathrm{C}, 47.29 ; \mathrm{H}, 2.44 ; \mathrm{N}, 21.21$. Found: $\mathrm{C}$, 47.26; H, 2.28; N, 21.07.

1,6-Diamino-4-(4-nitrophenyl)-2-oxo-1,2-dihydropyridine-3,5dicarbonitrile (4c). Yellow solid; yield: $0.269 \mathrm{~g}$ (91\%); mp: $360{ }^{\circ} \mathrm{C}$ (dec.); ${ }^{1} \mathrm{H}$ NMR (300 MHz, DMSO): $\delta 5.50$ (s, 2H, N-NH ${ }_{2}$ ), 7.84 (d, $J=9 \mathrm{~Hz}, 2 \mathrm{H}, \mathrm{ArH}$ ), 8.06 (brs, $2 \mathrm{H}, \mathrm{NH}_{2}$ ); 8.44 (d, $J=9 \mathrm{~Hz}, 2 \mathrm{H}$, ArH),${ }^{13} \mathrm{C}\left\{{ }^{1} \mathrm{H}\right\}$ NMR (75.4 MHz, DMSO): $\delta 74.6(C-\mathrm{CN}), 86.7(C-$ $\mathrm{CN}), 115.5$ (CN), $116.4(\mathrm{CN}), 124.3,130.2,141.3,148.9$ (Ar), 157.0 (C-4), $158\left(\mathrm{C}-\mathrm{NH}_{2}\right), 159.4(\mathrm{C}=\mathrm{O}) ; \mathrm{MS}(\mathrm{EI}, 70 \mathrm{eV}): \mathrm{m} / \mathrm{z}(\%)=297$ (17) $[\mathrm{M}+1]^{+}, 296(100)[\mathrm{M}]^{+}, 267$ (11), 252 (14), 230 (3), 205 (4), 193 (5), 165 (8), 152 (7), 126 (5), 100 (4), 88 (4), 58 (3), 43 (2); anal. calcd for $\mathrm{C}_{13} \mathrm{H}_{8} \mathrm{~N}_{6} \mathrm{O}_{3}: \mathrm{C}, 52.71 ; \mathrm{H}, 2.72 ; \mathrm{N}, 28.37$. Found: C, $52.64 ; \mathrm{H}, 2.53$; N, 28.19.

1,6-Diamino-4-(4-methoxyphenyl)-2-oxo-1,2-dihydropyridine3,5-dicarbonitrile (4d). Pale yellow solid; yield: $0.233 \mathrm{~g}$ (83\%); mp: 321-323 ${ }^{\circ} \mathrm{C}$; IR (KBr) $\left(\nu_{\max } / \mathrm{cm}^{-1}\right): 3393,3316,3264,2211$, 1640, 1513, 1419, 1256, 1023, 837; ${ }^{1} \mathrm{H}$ NMR (300 MHz, DMSO): $\delta 3.81\left(\mathrm{~s}, 3 \mathrm{H}, \mathrm{OCH}_{3}\right), 5.62\left(\mathrm{~s}, 2 \mathrm{H}, \mathrm{N}-\mathrm{NH}_{2}\right), 7.07(\mathrm{~d}, J=8.7 \mathrm{~Hz}, 2 \mathrm{H}$, ArH), 7.43 (d, $J=8.7 \mathrm{~Hz}, 2 \mathrm{H}, \mathrm{ArH}), 8.40$ (brs, $\left.2 \mathrm{H}, \mathrm{NH}_{2}\right) ;{ }^{13} \mathrm{C}\left\{{ }^{1} \mathrm{H}\right\}$ NMR (75.4 MHz, DMSO): $\delta 55.79\left(\mathrm{OCH}_{3}\right), 74.7(C-\mathrm{CN}), 86.7(C-$ $\mathrm{CN}), 114.4(\mathrm{CN}), 116.2(\mathrm{CN}), 117,126.9,130.3,157.7$ (Ar), 159.7 (C-4), $159.8\left(\mathrm{C}-\mathrm{NH}_{2}\right), 161.1(\mathrm{C}=\mathrm{O}) ; \mathrm{MS}(\mathrm{EI}, 70 \mathrm{eV}): \mathrm{m} / \mathrm{z}(\%)=282$ (18) $[\mathrm{M}+1]^{+}, 281(100)[\mathrm{M}]^{+}, 266$ (4), 252 (18), 237 (27), 210 (13), 195 (8), 180 (6), 167 (5), 140 (3), 114 (9), 88 (6), 58 (4), 43 (7); anal. calcd for $\mathrm{C}_{14} \mathrm{H}_{11} \mathrm{~N}_{5} \mathrm{O}_{2}$ : C, 59.78; H, 3.94; N, 24.90. Found: C, 59.39 ; H, 3.79; N, 24.85.

1,6-Diamino-4-(3-methoxyphenyl)-2-oxo-1,2-dihydropyridine3,5-dicarbonitrile (4e). White solid; yield: $0.238 \mathrm{~g}$ (85\%); mp: 265-267 ${ }^{\circ} \mathrm{C}$; IR (KBr) $\left(\nu_{\max } / \mathrm{cm}^{-1}\right): 3425,3314,3194,2954,2205$, 1682, 1617, 1526, 1464, 1292, 1159, 884; ${ }^{1} \mathrm{H}$ NMR $(300 \mathrm{MHz}$, DMSO): $\delta 3.78\left(\mathrm{~s}, 3 \mathrm{H}, \mathrm{OCH}_{3}\right), 5.57\left(\mathrm{~s}, 2 \mathrm{H}, \mathrm{N}-\mathrm{NH}_{2}\right), 6.99-7.10(\mathrm{~m}$, $3 \mathrm{H}, \mathrm{ArH}), 7.44(\mathrm{t}, J=8.1 \mathrm{~Hz}, 1 \mathrm{H}, \mathrm{ArH}), 8.44$ (brs, $\left.2 \mathrm{H}, \mathrm{NH}_{2}\right) ;{ }^{13} \mathrm{C}$ $\left\{{ }^{1} \mathrm{H}\right\}$ NMR (75.4 MHz, DMSO): $\delta 55.78\left(\mathrm{OCH}_{3}\right), 74.7(C-\mathrm{CN}), 86.8$ $(C-\mathrm{CN}), 114.1(\mathrm{CN}), 115.8(\mathrm{CN}), 116,116.7,120.5,130.3,136.2$, 157 (Ar), 159.4 (C-4), $159.6\left(\mathrm{C}-\mathrm{NH}_{2}\right), 159.7$ (C=O); MS (EI, 70 $\mathrm{eV}): m / z(\%)=282(18)[\mathrm{M}+1]^{+}, 281(100)[\mathrm{M}]^{+}, 280(22), 265(5)$, 252 (18), 237 (16), 210 (3), 195 (7), 180 (6), 167 (5), 140 (6), 114 (6), 88 (5), 63 (5), 43 (2); anal. calcd for $\mathrm{C}_{14} \mathrm{H}_{11} \mathrm{~N}_{5} \mathrm{O}_{2}$ : C, 59.78; $\mathrm{H}$, 3.94; N, 24.90. Found: C, 59.60; H, 3.84; N, 24.85 . 


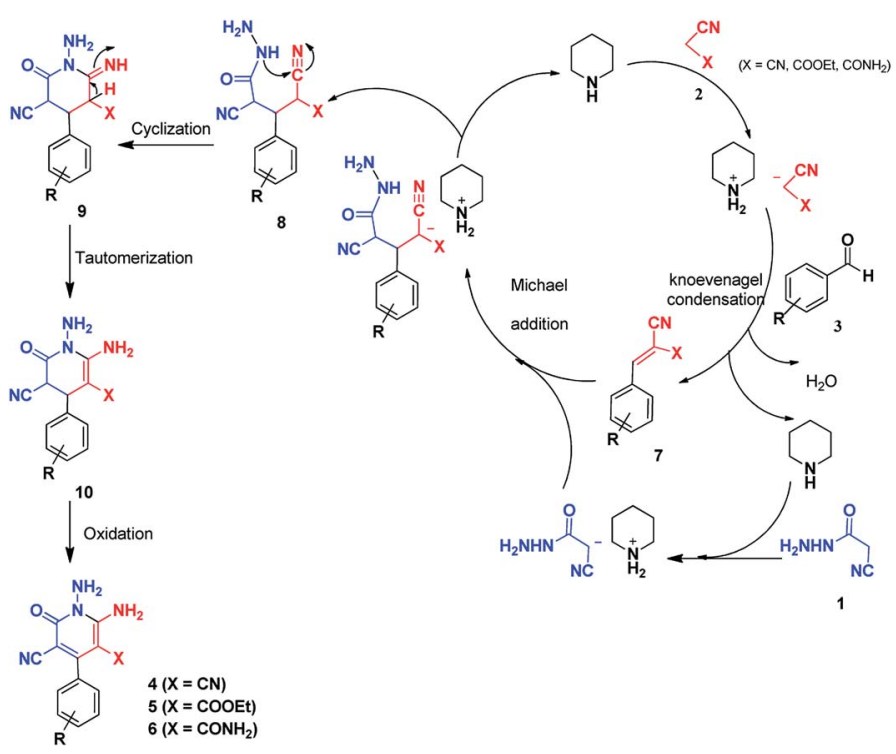

Scheme 4 Proposed mechanism for the formation of products 4, 5, 6 .

1,6-Diamino-4-phenyl-2-oxo-1,2-dihydropyridine-3,5dicarbonitrile (4f). White solid; yield: $0.225 \mathrm{~g}$ (90\%); mp: 332$334{ }^{\circ} \mathrm{C}$; IR (KBr) $\left(\nu_{\max } / \mathrm{cm}^{-1}\right)$ : 3444, 3397, 3240, 2212, 1630, 1525, 1469, 1219, 858, 739; ${ }^{1} \mathrm{H}$ NMR (300 MHz, DMSO): $\delta 5.64$ (s, 2H, $\mathrm{N}-\mathrm{NH}_{2}$ ), 7.36-7.52 (m, 5H, ArH), 8.45 (brs, $2 \mathrm{H}, \mathrm{NH}_{2}$ ); ${ }^{13} \mathrm{C}\left\{{ }^{1} \mathrm{H}\right\}$ NMR (75.4 MHz, DMSO): $\delta 74.7(C-\mathrm{CN}), 86.8(C-\mathrm{CN}), 115.9(\mathrm{CN})$, 116.8 (CN), 128.4, 129, 130.6, 135 (Ar), 157.1 (C-4), 159.7 (C$\left.\mathrm{NH}_{2}\right), 160(\mathrm{C}=\mathrm{O}) ; \mathrm{MS}(\mathrm{EI}, 70 \mathrm{eV}): \mathrm{m} / z(\%)=252(18)[\mathrm{M}+1]^{+}, 251$ (100) [M] $]^{+}, 236$ (2), 222 (21), 207 (26), 194 (7), 180 (17), 165 (8), 127 (14), 88 (5), 77 (12), 51 (10), 43 (4); anal. calcd for $\mathrm{C}_{13} \mathrm{H}_{9} \mathrm{~N}_{5} \mathrm{O}$ : C, 62.15; H, 3.61; N, 27.87. Found: C, 61.79; H, 3.56; N, 27.62.

1,6-Diamino-4-(2-chlorophenyl)-2-oxo-1,2-dihydropyridine3,5-dicarbonitrile (4g). White solid; yield: $0.247 \mathrm{~g}$ (87\%); mp: 305-307 ${ }^{\circ} \mathrm{C}$; IR (KBr) $\left(\nu_{\max } / \mathrm{cm}^{-1}\right): 3411,3305,3205,2213,1678$, 1561, 1466, 1228, 880, 757; ${ }^{1} \mathrm{H}$ NMR (300 MHz, DMSO): $\delta 5.66(\mathrm{~s}$, $2 \mathrm{H}, \mathrm{N}-\mathrm{NH}_{2}$ ), $7.41-7.66$ (m, $\left.4 \mathrm{H}, \mathrm{ArH}\right), 8.59$ (brs, $2 \mathrm{H}, \mathrm{NH}_{2}$ ); ${ }^{13} \mathrm{C}$ $\left\{{ }^{1} \mathrm{H}\right\}$ NMR (75.4 MHz, DMSO): $\delta 75.3(C-\mathrm{CN}), 87.5(C-\mathrm{CN}), 115.1$ (CN), $116(\mathrm{CN}), 128.2,130.1,130.2,131,132.1,134.2(\mathrm{Ar}), 157(\mathrm{C}-$ 4), $157.7\left(\mathrm{C}-\mathrm{NH}_{2}\right), 159.5(\mathrm{C}=\mathrm{O})$; $\mathrm{MS}(\mathrm{EI}, 70 \mathrm{eV}): \mathrm{m} / z(\%)=287$ (37) $[\mathrm{M}+2]^{+}, 286(30)[\mathrm{M}+1]^{+}, 285(100)[\mathrm{M}]^{+}, 276(3), 250(23)$, 222 (4), 205 (13), 193 (10), 161 (12), 138 (10), 111 (5), 88 (6), 67 (3), 58 (4), 43 (2); anal. calcd for $\mathrm{C}_{13} \mathrm{H}_{8} \mathrm{ClN}_{5} \mathrm{O}: \mathrm{C}, 54.65 ; \mathrm{H}$, 2.82 ; N, 24.51. Found: C, 55.14; H, 2.45; N, 24.31 .

1,6-Diamino-4-(3-chlorophenyl)-2-oxo-1,2-dihydropyridine3,5-dicarbonitrile (4h). White solid; yield: $0.242 \mathrm{~g}$ (85\%); mp: 292-294 ${ }^{\circ} \mathrm{C} ;{ }^{1} \mathrm{H}$ NMR (300 MHz, DMSO): $\delta 5.66\left(\mathrm{~s}, 2 \mathrm{H}, \mathrm{N}-\mathrm{NH}_{2}\right.$ ), 7.42-7.62 (m, 4H, ArH), 8.52 (brs, $\left.2 \mathrm{H}, \mathrm{NH}_{2}\right) ;{ }^{13} \mathrm{C}\left\{{ }^{1} \mathrm{H}\right\}$ NMR (75.4 MHz, DMSO): $\delta 74.8$ (C-CN), $86.9(C-\mathrm{CN}), 115.7(\mathrm{CN}), 116.6$ (CN), 127.2, 128.2, 130.5, 131.1, 133.6, 137 (Ar), 157 (C-4), 158.4 $\left(\mathrm{C}-\mathrm{NH}_{2}\right), 159.5(\mathrm{C}=\mathrm{O})$; anal. calcd for $\mathrm{C}_{13} \mathrm{H}_{8} \mathrm{ClN}_{5} \mathrm{O}: \mathrm{C}, 54.65 ; \mathrm{H}$, 2.82; N, 24.51. Found: C, 55.53; H, 2.67; N, 24.50.

1,6-Diamino-2-oxo-4-(4-(trifluoromethyl)phenyl)-1,2dihydropyridine-3,5-dicarbonitrile (4i). Pale brown solid; yield: $0.255 \mathrm{~g}$ (80\%); mp: $290-293{ }^{\circ} \mathrm{C} ;{ }^{1} \mathrm{H}$ NMR $(300 \mathrm{MHz}$, DMSO): $\delta 5.61\left(\mathrm{~s}, 2 \mathrm{H}, \mathrm{N}-\mathrm{NH}_{2}\right), 7.72(\mathrm{~d}, J=8.1 \mathrm{~Hz}, 2 \mathrm{H}, \mathrm{ArH}), 7.93$ $(\mathrm{d}, J=8.1 \mathrm{~Hz}, 2 \mathrm{H}, \mathrm{ArH}), 8.57$ (brs, $\left.2 \mathrm{H}, \mathrm{NH}_{2}\right) ;{ }^{13} \mathrm{C}\left\{{ }^{1} \mathrm{H}\right\} \mathrm{NMR}(75.4$ MHz, DMSO): $\delta 74.7(C-\mathrm{CN}), 86.8(C-\mathrm{CN}), 115.6(\mathrm{CN}), 116.5$ (CN), $122.5\left(\mathrm{CF}_{3}\right), 126.1,129.5,131.03,139.1,135.5$ (Ar), 157.1 (C-4), $158.6\left(\mathrm{C}-\mathrm{NH}_{2}\right), 159.5(\mathrm{C}=\mathrm{O}) ; \mathrm{MS}(\mathrm{EI}, 70 \mathrm{eV}): m / z(\%)=320$ (17) $[\mathrm{M}+1]^{+}, 319(100)[\mathrm{M}]^{+}, 300$ (12), 275 (24), 248 (10), 195 (11), 176 (10), 145 (9), 111 (4), 99 (6), 88 (5), 69 (15), 57 (8), 43 (11); anal. calcd for $\mathrm{C}_{14} \mathrm{H}_{8} \mathrm{~F}_{3} \mathrm{~N}_{5} \mathrm{O}: \mathrm{C}, 52.67 ; \mathrm{H}, 2.53 ; \mathrm{N}, 21.94$. Found: C, 52.35; H, 2.81; N, 21.67.

1,6-Diamino-4-(3,4-dimethoxyphenyl)-2-oxo-1,2-dihydropyridine3,5-dicarbonitrile (4j). Pale yellow solid; yield: $0.233 \mathrm{~g}$ (75\%); mp: 290-292 ${ }^{\circ} \mathrm{C}$; IR (KBr) $\left(\nu_{\max } / \mathrm{cm}^{-1}\right): 3402,3291,2966,2845,2215$, $1673,1613,152,1464,1269,1153,1019,866,762 ;{ }^{1} \mathrm{H}$ NMR (300 MHz, DMSO): $\delta 3.77\left(\mathrm{~s}, 3 \mathrm{H}, \mathrm{OCH}_{3}\right), 3.81\left(\mathrm{~s}, 3 \mathrm{H}, \mathrm{OCH}_{3}\right), 5.64(\mathrm{~s}$, $2 \mathrm{H}, \mathrm{N}-\mathrm{NH}_{2}$ ), 7.02-7.10 (m, 3H, ArH), 8.40 (brs, $\left.2 \mathrm{H}, \mathrm{NH}_{2}\right) ;{ }^{13} \mathrm{C}$ $\left\{{ }^{1} \mathrm{H}\right\} \mathrm{NMR}(75.4 \mathrm{MHz}, \mathrm{DMSO}): \delta 56\left(\mathrm{OCH}_{3}\right), 56.1\left(\mathrm{OCH}_{3}\right), 74.7(C-$ $\mathrm{CN}), 86.7(C-\mathrm{CN}), 111.84,112.4(\mathrm{Ar}), 116.2(\mathrm{CN}), 117.1(\mathrm{CN})$, 121.6, 126.9, 148.6, 150.7 (Ar), 157.1 (C-4), 159.7 (C-NH $\left.{ }_{2}\right), 159.8$ $(\mathrm{C}=\mathrm{O}) ; \mathrm{MS}(\mathrm{EI}, 70 \mathrm{eV}): \mathrm{m} / \mathrm{z}(\%)=312(24)[\mathrm{M}+1]^{+}, 311(100)$ $[\mathrm{M}]^{+}, 296$ (7), 268 (13), 237 (5), 209 (4), 181 (4), 151 (10), 127 (3), 101 (3), 88 (2), 77 (3), 58 (2), 43 (3); anal. calcd for $\mathrm{C}_{15} \mathrm{H}_{13} \mathrm{~N}_{5} \mathrm{O}_{3}: \mathrm{C}$, 57.87; H, 4.21; N, 22.50. Found: C, 57.60; H, 4.20; N, 22.22.

1,6-Diamino-4-(4-fluorophenyl)-2-oxo-1,2-dihydropyridine-3,5dicarbonitrile (4k). White solid; yield: $0.223 \mathrm{~g}$ (83\%); mp: 338$340{ }^{\circ} \mathrm{C}$; IR (KBr) $\left(\nu_{\max } / \mathrm{cm}^{-1}\right): 3390,3287,3196,2211,1627,1516$, 1463, 1224, 1157, 945, 848, 616; ${ }^{1} \mathrm{H}$ NMR (300 MHz, DMSO): $\delta 5.65\left(\mathrm{~s}, 2 \mathrm{H}, \mathrm{N}-\mathrm{NH}_{2}\right), 7.35-7.57$ (m, 4H, ArH), 8.49 (brs, 2H, $\left.\mathrm{NH}_{2}\right) ;{ }^{13} \mathrm{C}\left\{{ }^{1} \mathrm{H}\right\}$ NMR (75.4 MHz, DMSO): $\delta 74.9(C-\mathrm{CN}), 87(C-$ $\mathrm{CN}), 115.9(\mathrm{CN}), 116$ (CN), 116.5, 131.1, 131.4, 163.4 (Ar), 157 (C4), $159\left(\mathrm{C}-\mathrm{NH}_{2}\right), 159.6(\mathrm{C}=\mathrm{O})$; anal. calcd for $\mathrm{C}_{13} \mathrm{H}_{8} \mathrm{FN}_{5} \mathrm{O}: \mathrm{C}$, 57.99; H, 2.99; N, 26.01. Found: C, 57.95, 2.89; 25.87.

1,6-Diamino-4-(3-fluorophenyl)-2-oxo-1,2-dihydropyridine-3,5dicarbonitrile (41). White solid; yield: $0.209 \mathrm{~g}$ (78\%); mp: $340{ }^{\circ} \mathrm{C}$ (dec.); IR (KBr) $\left(\nu_{\max } / \mathrm{cm}^{-1}\right): 3382,3298,3206,2215,1619,1527$, 1465, 1244, 1019, 965, 884, 761; ${ }^{1} \mathrm{H}$ NMR (300 MHz, DMSO): $\delta 5.66\left(\mathrm{~s}, 2 \mathrm{H}, \mathrm{N}-\mathrm{NH}_{2}\right), 7.29-7.62(\mathrm{~m}, 4 \mathrm{H}, \mathrm{ArH}), 8.52$ (brs, 2H, 
$\left.\mathrm{NH}_{2}\right) ;{ }^{13} \mathrm{C}\left\{{ }^{1} \mathrm{H}\right\}$ NMR (75.4 MHz, DMSO): $\delta 74.8(C-\mathrm{CN}), 86.9(C-$ $\mathrm{CN}), 115.6(\mathrm{Ar}), 115.8(\mathrm{CN}), 116.5(\mathrm{CN}), 117.5,124.7,131.4$, 137.1, 162.1 (Ar), 157 (C-4), $158.5\left(\mathrm{C}-\mathrm{NH}_{2}\right), 159.5(\mathrm{C}=\mathrm{O})$; anal. calcd for $\mathrm{C}_{13} \mathrm{H}_{8} \mathrm{FN}_{5} \mathrm{O}: \mathrm{C}, 57.99 ; \mathrm{H}, 2.99 ; \mathrm{N}, 26.01$. Found: C, 56.73; H, 3.83; N, 24.11.

General procedure for the synthesis of ethyl 1,6-diamino-4aryl-3-cyano-2-oxo-1,2-dihydropyridine-5-carboxylate (5a-e)

The stoichiometric mixture of cyanoacetohydrazide 1 ( $1 \mathrm{mmol}$, $0.99 \mathrm{~g})$, ethyl cyanoacetate $2 \mathrm{~b}(1 \mathrm{mmol}, 0.113 \mathrm{~g})$, aromatic aldehyde $(1 \mathrm{mmol})$ and piperidine $(20 \% \mathrm{~mol}, 0.019 \mathrm{ml})$ in a mixture of $\mathrm{H}_{2} \mathrm{O}$ and ethanol $(5: 5 \mathrm{ml})$ was stirred at $80{ }^{\circ} \mathrm{C}$. Upon completion the reaction as monitored by TLC (using ethyl acetate/n-hexane $(1: 1))$, the precipitated product was collected by filtration and washed with $\mathrm{H}_{2} \mathrm{O} / \mathrm{EtOH}$ to give the pure products $\mathbf{5 a - e . ~}$

Ethyl 1,6-diamino-4-(4-chlorophenyl)-3-cyano-2-oxo-1,2dihydropyridine-5-carboxylate (5a). White solid; yield: $0.288 \mathrm{~g}$ (87\%); mp: $245-247^{\circ} \mathrm{C}$; IR (KBr) $\left(\nu_{\max } / \mathrm{cm}^{-1}\right): 3387,3226$, 2984, 2923, 2215, 1686, 1651, 1585, 1473, 1207, 1092, 839, 618; ${ }^{1} \mathrm{H}$ NMR (300 MHz, DMSO): $\delta 0.57\left(\mathrm{t}, J=7.2 \mathrm{~Hz}, 3 \mathrm{H}, \mathrm{CH}_{3}\right), 3.73$ (q, $\left.J=7.2 \mathrm{~Hz}, 2 \mathrm{H}, \mathrm{CH}_{2}\right), 5.67\left(\mathrm{~s}, 2 \mathrm{H}, \mathrm{N}-\mathrm{NH}_{2}\right), 7.25(\mathrm{~d}, J=8.4 \mathrm{~Hz}$, $2 \mathrm{H}, \mathrm{ArH}), 7.49$ (d, $J=8.4 \mathrm{~Hz}, 2 \mathrm{H}, \mathrm{ArH}), 8.42$ (brs, $1 \mathrm{H}, \mathrm{NH}_{2}$ ), 8.72 (brs, $\left.1 \mathrm{H}, \mathrm{NH}_{2}\right) ;{ }^{13} \mathrm{C}\left\{{ }^{1} \mathrm{H}\right\} \mathrm{NMR}(75.4 \mathrm{MHz}, \mathrm{DMSO}): \delta 13.2\left(\mathrm{CH}_{3}\right)$, $60.5\left(\mathrm{O}-\mathrm{CH}_{2}\right), 88.1(\mathrm{C}-\mathrm{CN}), 91.4\left(\mathrm{C}-\mathrm{CO}_{2} \mathrm{Et}\right), 117(\mathrm{CN}), 128.4$, 129.2, 133.4, 138.1 (Ar), $156.6(\mathrm{C}-4), 158.6\left(\mathrm{C}-\mathrm{NH}_{2}\right), 159.2(\mathrm{C}=$ O), $166.1\left(\mathrm{CO}_{2} \mathrm{Et}\right)$; MS (EI, $\left.70 \mathrm{eV}\right): \mathrm{m} / z(\%)=334(35)[\mathrm{M}+2]^{+}, 333$ (21) $[\mathrm{M}+1]^{+}, 332(100)[\mathrm{M}]^{+}, 303$ (5), 286 (13), 251 (13), 229 (21), 187 (5), 162 (12), 138 (7), 111 (4), 75 (4), 58 (3), 43 (5); anal. calcd for $\mathrm{C}_{15} \mathrm{H}_{13} \mathrm{ClN}_{4} \mathrm{O}_{3}$ : C, 54.14; H, 3.94; N, 16.84. Found: C, 53.86; $\mathrm{H}, 3.74 ; \mathrm{N}, 16.47$.

Ethyl 1,6-diamino-4-(4-bromophenyl)-3-cyano-2-oxo-1,2dihydropyridine-5-carboxylate (5b). White solid; yield: $0.319 \mathrm{~g}$ (85\%); mp: $245-247^{\circ} \mathrm{C}$; IR (KBr) $\left(\nu_{\max } / \mathrm{cm}^{-1}\right): 3391,3270$, 2216, 1686, 1588, 1537, 1471, 1207, 1091, 878, 768, 615; ${ }^{1} \mathrm{H}$ NMR (300 MHz, DMSO): $\delta 0.57\left(\mathrm{t}, J=6.9 \mathrm{~Hz}, 3 \mathrm{H}, \mathrm{CH}_{3}\right), 3.73(\mathrm{q}, J=$ $\left.6.9 \mathrm{~Hz}, 2 \mathrm{H}, \mathrm{CH}_{2}\right), 5.66\left(\mathrm{~s}, 2 \mathrm{H}, \mathrm{N}-\mathrm{NH}_{2}\right), 7.19(\mathrm{~d}, J=8.1 \mathrm{~Hz}, 2 \mathrm{H}$, $\mathrm{ArH}), 7.62$ (d, $J=8.1 \mathrm{~Hz}, 2 \mathrm{H}, \mathrm{ArH}), 8.42$ (brs, $1 \mathrm{H}, \mathrm{NH}_{2}$ ), 8.72 (brs, $\left.1 \mathrm{H}, \mathrm{NH}_{2}\right) ;{ }^{13} \mathrm{C}\left\{{ }^{1} \mathrm{H}\right\}$ NMR (75.4 MHz, DMSO): $\delta 13.1\left(\mathrm{CH}_{3}\right), 60.5$ $\left(\mathrm{O}-\mathrm{CH}_{2}\right), 88(\mathrm{C}-\mathrm{CN}), 91.3\left(\mathrm{C}-\mathrm{CO}_{2} \mathrm{Et}\right), 117(\mathrm{CN}), 121.9,129.5$, 131.3, 138.5 (Ar), $156.6(\mathrm{C}-4), 158.6\left(\mathrm{C}-\mathrm{NH}_{2}\right), 159.2(\mathrm{C}=\mathrm{O}), 166.1$ $\left(\mathrm{CO}_{2} \mathrm{Et}\right) ; \mathrm{MS}(\mathrm{EI}, 70 \mathrm{eV}): \mathrm{m} / z(\%)=379(19)[\mathrm{M}+2]^{+}, 378$ (100) $[\mathrm{M}+1]^{+}, 377$ (21) $[\mathrm{M}]^{+}, 376$ (99), 349 (4), 332 (9), 304 (9), 275 (18), 223 (18), 194 (14), 152 (8), 127 (12), 100 (5), 88 (5), 43 (3); anal. calcd for $\mathrm{C}_{15} \mathrm{H}_{13} \mathrm{BrN}_{4} \mathrm{O}_{3}: \mathrm{C}, 47.76 ; \mathrm{H}, 3.47 ; \mathrm{N}, 14.85$. Found: $\mathrm{C}$, 47.43; H, 3.75; N, 14.53 .

Ethyl 1,6-diamino-4-(2-chlorophenyl)-3-cyano-2-oxo-1,2dihydropyridine-5-carboxylate (5c). White solid; yield: $0.265 \mathrm{~g}$ (80\%); mp: $322-324{ }^{\circ} \mathrm{C}$; IR (KBr) $\left(\nu_{\max } / \mathrm{cm}^{-1}\right): 3386,3269$, 2214, 1653, 1584, 1456, 1312, 1213, 1006, 800, 621; ${ }^{1} \mathrm{H}$ NMR $(300$ MHz, DMSO): $\delta 0.55\left(\mathrm{t}, J=6.9 \mathrm{~Hz}, 3 \mathrm{H}, \mathrm{CH}_{3}\right), 3.73(\mathrm{q}, J=6.9 \mathrm{~Hz}$, $2 \mathrm{H}, \mathrm{CH}_{2}$ ), 5.69 (s, 2H, N-NH ${ }_{2}$ ), 7.24-7.52 (m, 4H, ArH), 8.47 (brs, $1 \mathrm{H}, \mathrm{NH}_{2}$ ), 9.00 (brs, $1 \mathrm{H}, \mathrm{NH}_{2}$ ); ${ }^{13} \mathrm{C}\left\{{ }^{1} \mathrm{H}\right\} \mathrm{NMR}$ (75.4 MHz, DMSO): $\delta 13.2\left(\mathrm{CH}_{3}\right), 60.5\left(\mathrm{O}-\mathrm{CH}_{2}\right), 88.5(\mathrm{C}-\mathrm{CN}), 91\left(\mathrm{C}-\mathrm{CO}_{2} \mathrm{Et}\right), 116.4$ (CN), 127.4, 129, 129.3, 130.2, 130.7, 138.4 (Ar), 157 (C-4), 159.2 $\left(\mathrm{C}-\mathrm{NH}_{2}\right), 159.2(\mathrm{C}=\mathrm{O}), 165.8\left(\mathrm{CO}_{2} \mathrm{Et}\right) ; \mathrm{MS}(\mathrm{EI}, 70 \mathrm{eV}): m / z(\%)=$
$334(6)[\mathrm{M}+2]^{+}, 333(3)[\mathrm{M}+1]^{+}, 332(17)[\mathrm{M}]^{+}, 297(100), 269$ (95), 253 (12), 224 (11), 174 (6), 138 (7), 113 (3), 99 (3), 75 (3), 58 (2), 43 (2); anal. calcd for $\mathrm{C}_{15} \mathrm{H}_{13} \mathrm{ClN}_{4} \mathrm{O}_{3}$ : C, 54.14; H, 3.94; N, 16.84. Found: C, 56.05; H, 4.04; N, 16.71.

Ethyl 1,6-diamino-4-(3-fluorophenyl)-3-cyano-2-oxo-1,2dihydropyridine-5-carboxylate (5d). White solid; yield: $0.237 \mathrm{~g}(75 \%)$; mp: $218-220^{\circ} \mathrm{C}$; IR (KBr) $\left(\nu_{\max } / \mathrm{cm}^{-1}\right): 3390,3268$, 2217, 1687, 1652, 1537, 1456, 1310, 1208, 1096, 884; ${ }^{1} \mathrm{H}$ NMR (300 MHz, DMSO): $\delta 0.57\left(\mathrm{t}, J=7.2 \mathrm{~Hz}, 3 \mathrm{H}, \mathrm{CH}_{3}\right), 3.74(\mathrm{q}, J=$ $\left.7.2 \mathrm{~Hz}, 2 \mathrm{H}, \mathrm{CH}_{2}\right), 5.68$ (s, 2H, N-NH $)_{2}, 7.05$ (d, $J=7.8 \mathrm{~Hz}, 1 \mathrm{H}$, $\operatorname{ArH}), 7.14$ (d, $J=9.6 \mathrm{~Hz}, 1 \mathrm{H}, \operatorname{ArH}), 7.25$ (t, $J=8.4 \mathrm{~Hz}, 1 \mathrm{H}, \operatorname{ArH})$, 7.45 (q, $J=8.1 \mathrm{~Hz}, 1 \mathrm{H}, \mathrm{ArH}), 8.43$ (brs, $1 \mathrm{H}, \mathrm{NH}_{2}$ ), 8.78 (brs, $1 \mathrm{H}$, $\left.\mathrm{NH}_{2}\right) ;{ }^{13} \mathrm{C}\left\{{ }^{1} \mathrm{H}\right\}$ NMR (75.4 MHz, DMSO): $\delta 13.2\left(\mathrm{CH}_{3}\right), 60.4(\mathrm{O}-$ $\mathrm{CH}_{2}$ ), $88.2(\mathrm{C}-\mathrm{CN}), 91.3\left(\mathrm{C}-\mathrm{CO}_{2} \mathrm{Et}\right), 116.9(\mathrm{CN}), 114.5,115.3$, 123.6, 130.5, 141.4, 163.8 (Ar), 156.7 (C-4), $158.3\left(\mathrm{C}-\mathrm{NH}_{2}\right), 159.1$ $(\mathrm{C}=\mathrm{O}), 166.1\left(\mathrm{CO}_{2} \mathrm{Et}\right)$; MS (EI, $\left.70 \mathrm{eV}\right): m / z(\%)=317$ (19) $[\mathrm{M}+$ $1]^{+}, 316$ (100) [M] $]^{+}, 287$ (4), 270 (30), 213 (26), 171 (6), 146 (13), 111 (2), 75 (3), 58 (2), 43 (2); anal. calcd for $\mathrm{C}_{15} \mathrm{H}_{13} \mathrm{FN}_{4} \mathrm{O}_{3}: \mathrm{C}$, 56.96; H, 4.14; N, 17.71. Found: C, 56.42; H, 4.28; N, 17.34.

Ethyl 1,6-diamino-4-(4-fluorophenyl)-3-cyano-2-oxo-1,2dihydropyridine-5-carboxylate (5e). White solid; yield: $0.237 \mathrm{~g}$ (75\%); mp: 237-239 ${ }^{\circ} \mathrm{C}$; ${ }^{1} \mathrm{H}$ NMR (300 MHz, DMSO): $\delta 0.59\left(\mathrm{t}, J=7.2 \mathrm{~Hz}, 3 \mathrm{H}, \mathrm{CH}_{3}\right), 3.73\left(\mathrm{q}, J=7.2 \mathrm{~Hz}, 2 \mathrm{H}, \mathrm{CH}_{2}\right), 5.66$ (s, 2H, N-NH $\mathrm{NH}_{2}$ ) 7.26 (d, $\left.J=7.8 \mathrm{~Hz}, 4 \mathrm{H}, \mathrm{ArH}\right), 8.55$ (br, 2H, $\mathrm{NH}_{2}$ ); ${ }^{13} \mathrm{C}\left\{{ }^{1} \mathrm{H}\right\}$ NMR (75.4 MHz, DMSO): $\delta 13.2\left(\mathrm{CH}_{3}\right), 60.5\left(\mathrm{O}-\mathrm{CH}_{2}\right)$, $88.2(C-\mathrm{CN}), 91.7\left(C-\mathrm{CO}_{2} \mathrm{Et}\right), 117.1(\mathrm{CN}), 115.4,129.5,135.5$, 163.2 (Ar), 156.5 (C-4), $158.9\left(\mathrm{C}-\mathrm{NH}_{2}\right), 159.3(\mathrm{C}=\mathrm{O}), 166.2$ $\left(\mathrm{CO}_{2} \mathrm{Et}\right)$; anal. calcd for $\mathrm{C}_{15} \mathrm{H}_{13} \mathrm{FN}_{4} \mathrm{O}_{3}$ : C, 56.96; $\mathrm{H}, 4.14 ; \mathrm{N}, 17.71$. Found: C, 56.14; H, 4.08; N, 17.61 .

General procedure for the synthesis of 1,6-diamino-4-aryl-3cyano-2-oxo-1,2-dihydropyridine-5-carboxamide (6a-e)

The stoichiometric mixture of cyanoacetohydrazide 1 ( $1 \mathrm{mmol}$, $0.99 \mathrm{~g}$ ), cyanoacetamide $2 \mathrm{c}$ ( $1 \mathrm{mmol}, 0.084 \mathrm{~g}$ ), aromatic aldehyde $(1 \mathrm{mmol})$ and piperidine $(20 \% \mathrm{~mol}, 0.019 \mathrm{ml})$ in a mixture of $\mathrm{H}_{2} \mathrm{O}$ and ethanol $(3: 6 \mathrm{ml})$ was stirred at $80{ }^{\circ} \mathrm{C}$. After completion of the reaction that was monitored by TLC (using ethyl acetate/ $n$-hexane $(1: 1))$, the precipitated product was collected by filtration and washed with $\mathrm{H}_{2} \mathrm{O} / \mathrm{EtOH}$ to give the pure products $6 \mathbf{6}-\mathbf{e}$.

1,6-Diamino-4-(4-bromophenyl)-3-cyano-2-oxo-1,2-dihydropyridine-5carboxamide (6a). Brown solid; yield: $0.278 \mathrm{~g}$ (80\%); mp: 245$247^{\circ} \mathrm{C}$; IR (KBr) $\left(\nu_{\max } / \mathrm{cm}^{-1}\right): 3394,3290,2205,1662,1612,1571$, 1463, 1399, 1267, 886, 579; ${ }^{1} \mathrm{H}$ NMR (300 MHz, DMSO): $\delta 5.67$ (s, $2 \mathrm{H}, \mathrm{N}-\mathrm{NH}_{2}$ ), 6.85 (brs, $1 \mathrm{H}, \mathrm{NH}_{2}$ ), 7.22 (brs, $\left.1 \mathrm{H}, \mathrm{NH}_{2}\right), 7.28$ (d, $J=$ $8.4 \mathrm{~Hz}, 2 \mathrm{H}, \mathrm{ArH}), 7.65$ (d, $J=8.4 \mathrm{~Hz}, 2 \mathrm{H}, \operatorname{ArH}), 7.78(\mathrm{~s}, 2 \mathrm{H}$, $\left.\mathrm{CONH}_{2}\right) ;{ }^{13} \mathrm{C}\left\{{ }^{1} \mathrm{H}\right\} \mathrm{NMR}(75.4 \mathrm{MHz}, \mathrm{DMSO}): \delta 83.7(C-\mathrm{CN}), 99.4$ $\left(C-\mathrm{CONH}_{2}\right), 118.1(\mathrm{CN}), 123,130.8,131.6,136.1$ (Ar), 153.8 (C-4), $154\left(\mathrm{C}-\mathrm{NH}_{2}\right), 159.6(\mathrm{C}=\mathrm{O}), 167.3\left(\mathrm{CONH}_{2}\right) ; \mathrm{MS}(\mathrm{EI}, 70 \mathrm{eV}): \mathrm{m} / \mathrm{z}$ $(\%)=350(16)[\mathrm{M}+2]^{+}, 349(99)[\mathrm{M}+1]^{+}, 348(64)[\mathrm{M}]^{+}, 347(100)$, 346 (51), 332 (5), 301 (5), 275 (4), 251 (43), 237 (8), 205 (16), 194 (24), 180 (9), 152 (9), 140 (18), 113 (8), 100 (9), 88 (8), 63 (9), 44 (22); anal. calcd for $\mathrm{C}_{13} \mathrm{H}_{10} \mathrm{BrN}_{5} \mathrm{O}_{2}$ : C, 44.85; H, 2.90; N, 20.12. Found: C, 41.97; H, 3.38; N, 17.42.

1,6-Diamino-4-(4-chlorophenyl)-3-cyano-2-oxo-1,2-dihydropyridine-5carboxamide (6b). Pale brown solid; yield: $0.236 \mathrm{~g}$ (78\%); mp: 280- 
$282{ }^{\circ} \mathrm{C}$; IR $(\mathrm{KBr})\left(\nu_{\max } / \mathrm{cm}^{-1}\right): 3386,3301,2208,1635,1574,1461$, 1398, 1268, 880, 585; ${ }^{1} \mathrm{H}$ NMR (300 MHz, DMSO): $\delta 5.67$ (s, 2H, $\mathrm{N}-\mathrm{NH}_{2}$ ), 6.83 (brs, $1 \mathrm{H}, \mathrm{NH}_{2}$ ), 7.21 (brs, $1 \mathrm{H}, \mathrm{NH}_{2}$ ), 7.35 (d, $J=$ $8.4 \mathrm{~Hz}, 2 \mathrm{H}, \mathrm{ArH}), 7.51$ (d, $J=8.4 \mathrm{~Hz}, 2 \mathrm{H}, \mathrm{ArH}$ ), 7.78 (brs, $2 \mathrm{H}$, $\left.\mathrm{CONH}_{2}\right) ;{ }^{13} \mathrm{C}\left\{{ }^{1} \mathrm{H}\right\}$ NMR (75.4 MHz, DMSO): $\delta 83.8(C-\mathrm{CN}), 99.4$ $\left(C-\mathrm{CONH}_{2}\right), 118.1(\mathrm{CN}), 128.7,130.5,134.3,135.7$ (Ar), $153.8(\mathrm{C}-$ 4), $154\left(\mathrm{C}-\mathrm{NH}_{2}\right), 159.6(\mathrm{C}=\mathrm{O}), 167.3\left(\mathrm{CONH}_{2}\right)$; anal. calcd for $\mathrm{C}_{13} \mathrm{H}_{10} \mathrm{ClN}_{5} \mathrm{O}_{2}$ : C, 51.41; H, 3.32; N, 23.06. Found: C, 51.87; H, $3.54 ; \mathrm{N}, 22.57$.

1,6-Diamino-4-(3-chlorophenyl)-3-cyano-2-oxo-1,2-dihydropyridine5-carboxamide (6c). White solid; yield: $0.227 \mathrm{~g}$ (75\%); mp: 322$324{ }^{\circ} \mathrm{C} ;{ }^{1} \mathrm{H}$ NMR (300 MHz, DMSO): $\delta 5.67$ (s, 2H, N-NH $), 6.91$ (brs, $1 \mathrm{H}, \mathrm{NH}_{2}$ ), 7.26 (brs, $1 \mathrm{H}, \mathrm{NH}_{2}$ ), 7.28-7.48 (m, 4H, ArH), 7.79 $\left(\mathrm{s}, 2 \mathrm{H}, \mathrm{CONH}_{2}\right) ;{ }^{13} \mathrm{C}\left\{{ }^{1} \mathrm{H}\right\} \mathrm{NMR}(75.4 \mathrm{MHz}, \mathrm{DMSO}): \delta 83.7(C-\mathrm{CN})$, $99.5\left(C-\mathrm{CONH}_{2}\right), 118(\mathrm{CN}), 127.4,128.4,129.4,130.5,133.1$, 138.8 (Ar), 153.3 (C-4), $153.9\left(\mathrm{C}-\mathrm{NH}_{2}\right), 159.6(\mathrm{C}=\mathrm{O}), 167.2$ $\left(\mathrm{CONH}_{2}\right)$; anal. calcd for $\mathrm{C}_{13} \mathrm{H}_{10} \mathrm{ClN}_{5} \mathrm{O}_{2}: \mathrm{C}, 51.41 ; \mathrm{H}, 3.32 ; \mathrm{N}$, 23.06.

1,6-Diamino-4-(2-chlorophenyl)-3-cyano-2-oxo-1,2-dihydropyridine5-carboxamide (6d). Pale brown solid; yield: $0.212 \mathrm{~g}$ (70\%); mp: 218-220 ${ }^{\circ} \mathrm{C} ;{ }^{1} \mathrm{H}$ NMR (300 MHz, DMSO): $\delta 5.69\left(\mathrm{~s}, 2 \mathrm{H}, \mathrm{N}-\mathrm{NH}_{2}\right.$ ), 6.37 (br, $1 \mathrm{H}, \mathrm{NH}_{2}$ ), 7.27 (br, $\left.1 \mathrm{H}, \mathrm{NH}_{2}\right), 7.42-7.54(\mathrm{~m}, 4 \mathrm{H}, \mathrm{ArH})$, 8.05 (s, 2H, $\left.\mathrm{CONH}_{2}\right) ;{ }^{13} \mathrm{C}\left\{{ }^{1} \mathrm{H}\right\} \mathrm{NMR}(75.4 \mathrm{MHz}, \mathrm{DMSO}): \delta 84.7(C-$ $\mathrm{CN}), 99.2\left(C-\mathrm{CONH}_{2}\right), 117.4(\mathrm{CN}), 127.4,130,130.6,131.1$, 131.4, 135.8 (Ar), 152.4 (C-4), $154.6\left(\mathrm{C}-\mathrm{NH}_{2}\right), 159.4(\mathrm{C}=\mathrm{O}), 166.8$ $\left(\mathrm{CONH}_{2}\right)$; anal. calcd for $\mathrm{C}_{13} \mathrm{H}_{10} \mathrm{ClN}_{5} \mathrm{O}_{2}: \mathrm{C}, 51.41 ; \mathrm{H}, 3.32 ; \mathrm{N}$, 23.06 .

1,6-Diamino-4-(4-fluorophenyl)-3-cyano-2-oxo-1,2-dihydropyridine5-carboxamide (6e). Pale brown solid; yield: $0.186 \mathrm{~g}$ (65\%); mp: 237-239 ${ }^{\circ} \mathrm{C} ;{ }^{1} \mathrm{H}$ NMR (300 MHz, DMSO): $\delta 5.66\left(\mathrm{~s}, 2 \mathrm{H}, \mathrm{N}-\mathrm{NH}_{2}\right.$ ), 6.77 (brs, $1 \mathrm{H}, \mathrm{NH}_{2}$ ), 7.21 (brs, $1 \mathrm{H}, \mathrm{NH}_{2}$ ), 7.25-7.37 (m, 4H, ArH), 7.77 (s, 2H, $\left.\mathrm{CONH}_{2}\right) ;{ }^{13} \mathrm{C}\left\{{ }^{1} \mathrm{H}\right\} \mathrm{NMR}$ (75.4 MHz, DMSO): $\delta 84.1(C-$ $\mathrm{CN}), 99.5\left(C-\mathrm{CONH}_{2}\right), 118.1(\mathrm{CN}), 115.6,130.9,131,133.2(\mathrm{Ar})$, 154 (C-4), $154.1\left(\mathrm{C}-\mathrm{NH}_{2}\right), 159.7(\mathrm{C}=\mathrm{O}), 167.4\left(\mathrm{CONH}_{2}\right)$; MS (EI, $70 \mathrm{eV}): m / z(\%)=288(9)[\mathrm{M}+1]^{+}, 287(51)[\mathrm{M}]^{+}, 286(21), 270$ (17), 241 (10), 205 (26), 177 (12), 146 (18), 122 (100), 109 (24), 95 (25), 75 (13), 57 (11), 44 (16); anal. calcd for $\mathrm{C}_{13} \mathrm{H}_{10} \mathrm{FN}_{5} \mathrm{O}_{2}$ : C, 54.36; H, 3.51; N, 24.38. Found: C, 56.09; H, 4.15; N, 19.43.

\section{Conclusion}

We have reported a novel and green one-pot synthesis of three classes of polysubstituted pyridine systems, 1,6-diamino-4-aryl3,5-dicyano-2-pyridone, ethyl 1,6-diamino-4-aryl-3-cyano-2pyridone-5-carboxylate and 1,6-diamino-4-aryl-3-cyano-2pyridone-5-carboxamide derivatives, via a three-component reaction between cyanoacetohydrazide, activated nitrile compounds and aromatic aldehydes. The present process includes some important advantages like easy operation mild reaction conditions, facile accessibility of reactants, simple workup procedure, the use of water or water/ethanol as green reaction medium, high atom economy and good to high yields.

\section{Conflicts of interest}

The authors declare no competing financial interest.

\section{Acknowledgements}

Financial support of this research from Imam Khomeini International University, Iran is gratefully acknowledged.

\section{Notes and references}

1 S. C. Benson, J. L. Gross and J. K. Snyder, J. Org. Chem., 1990, 55, 3257-3269.

2 A. Thomass, M. Chakraborty and H. Junjappa, Tetrahedron, 1990, 46, 577-586.

3 J. Wolff and M. Taddei, Tetrahedron, 1986, 42, 4267-4272.

4 E. C. Taylor, J. Heterocycl. Chem., 1990, 27, 1-12.

5 Y. Tominaga, S. Kohra, H. Honkawa and A. Hosomi, Heterocycles, 1989, 28, 1409.

6 Y. Tominaga, S. Mdokawa, Y. Shiroshita and A. Hosomi, J. Heterocycl. Chem., 1987, 24, 1365.

7 C. J. Shishoo, M. B. Devani, V. S. Bhadti, S. Ananthan and G. V. Ullas, Tetrahedron Lett., 1983, 24, 4611-4612.

8 Y. Tominaga, S. Kohra, H. Okuda, A. Ushirogouchi, Y. Matsuda and G. kobayshi, Chem. Pharm. Bull., 1984, 32, 122.

9 E. Hahn, in Lectures in Heterocyclic Chemistry IX, ed. R. N. Castle, Heterocorporation, Tampa, FL, 1990, p. 13.

10 F. Sanger, S. Coulson and A. R. Coulson, Proc. Natl. Acad. Sci. U. S. A., 1977, 74, 5463.

11 Y. Higashio and T. Shoji, Appl. Catal., A, 2004, 260, 251-259.

12 G. A. Youngdale, US Pat. 4288440, 1980Chem. Abstr., 1982, 96, 6596.

13 A. H. Todd, UK Pat. 1203,149, 1970Chem. Abstr., 1970, 73, 120509.

14 G. Lohaus, W. Dittmar and S. Afric, IN Pat. 6906036, 1968, Chem. Abstr., 1970, 73, 120508.

15 C. Gachet, M. Cattanea, P. Ohlmann, B. Lecchi, J. Cassel, P. Mannucci and J. P. Cazenave, Br. J. Haematol., 1995, 91, 434.

16 F. A. Yassin, Chem. Heterocycl. Compd., 2009, 45(1), 35-41.

17 J. K. Son, L. X. Zhao, A. Basnet, P. Thapa, R. Karki, T. C. Jeong, B. S. Jeong, C. S. Lee and E. S. Lee, Eur. J. Med. Chem., 2008, 43, 675-682.

18 B. Vacher, B. Bonnaud, P. Funes, N. Jubault and M. Kleven, J. Med. Chem., 1999, 42, 1648-1660.

19 M. T. Cocco, C. Congiu and V. Onnis, Eur. J. Med. Chem., 2003, 38, 37-47.

20 A. Abadi, O. Al-Deeb, A. Al-Afify and H. El-Kashef, Farmaco, 1999, 54, 195-201.

21 G. Ozturk, D. D. Erol, T. Uzbay and M. D. Aytemir, Farmaco, 2001, 56, 251-256.

22 P. Storck, A. Aubertin and D. S. Grierson, Tetrahedron Lett., 2005, 46, 2919-2922.

23 P. S. Ghosh, K. Manna, U. Banik, M. Das and P. Sarkar, Int. J. Pharm. Pharm. Sci., 2014, 6, 39-42.

24 F. F. Fleming, L. Yao, P. C. Ravikumar, L. Funk and B. C. Shook, J. Med. Chem., 2010, 53, 7902-7917.

25 J. M. Mirkovi, D. Z. Mijin and S. D. Petrovic, Hem. Ind., 2013, 67, 17-25. 
26 T. Murata, K. Shimizu, V. C. Manganiello, T. Tagawa and K. Okumura, Anticancer Drugs, 2002, 13(8), 875-880.

27 I. W. Cheney, S. Yan, T. Appleby, H. Walker, R. Hamatake and Z. Hong, Bioorg. Med. Chem. Lett., 2007, 17(6), 16791683.

28 N. A. Aqui and R. H. Vonderheide, Cancer Biol. Ther., 2008, $7(12)$, 1888-1889.

29 F. Hernández, A. Sánchez, P. Rendón-Vallejo and F. Delgado, Eur. J. Med. Chem., 2013, 70, 669-676.

30 L. Carles, K. Narkunan, S. Penlou, L. Rousset, D. Bouchu and M. A. Ciufolini, J. Org. Chem., 2002, 67, 4304-4308.

31 Z. Kibou, N. Cheikh, D. Villemin, N. Choukchou-Braham, B. Mostefa-Kara and M. Benabdallah, Int. J. Org. Chem., 2011, 1, 242-249.

32 D. Mijin and A. Marinkovic, Synth. Commun., 2006, 36, 193198.
33 S. K. Rai, S. Khanam, R. S. Khanna and A. K. Tewari, RSC Adv., 2014, 4, 44141-44145.

34 M. Seifi and H. Sheibani, Lett. Org. Chem., 2013, 10, 478-481. 35 L. Mosti, G. Menozzi, P. Schenone, P. Dorigo, R. M. Gaion and P. Belluco, Farmaco, 1992, 47, 427.

36 I. A. Ibarra, A. Islas-Jácome and E. González-Zamora, Org. Biomol. Chem., 2018, 16, 1402-1418.

37 G. Mari, M. Verboni, L. D. Crescentini, G. Favi, S. Santeusanio and F. Mantellini, Org. Chem. Front., 2018, 5, 2108-2114.

38 X. Chang, X. Zhang and Z. Chen, Org. Biomol. Chem., 2018, 16, 4279-4287.

39 G. L. Wu and Q. P. Wu, Adv. Synth. Catal., 2018, 360, 19491953.

40 A. H. Mostafa-Hussein, Heteroat. Chem., 1997, 8, 1-6.

41 M. R. H. Elmoghayar and A. G. A. El-Agamey, J. Heterocycl. Chem., 1984, 21, 1885. 